\title{
DOE/EIS-0081-Suppl. \\ Supplement Analysis II \\ of \\ Environmental Impacts Resulting \\ from \\ Modifications in the \\ West Valley Demonstration Project
}

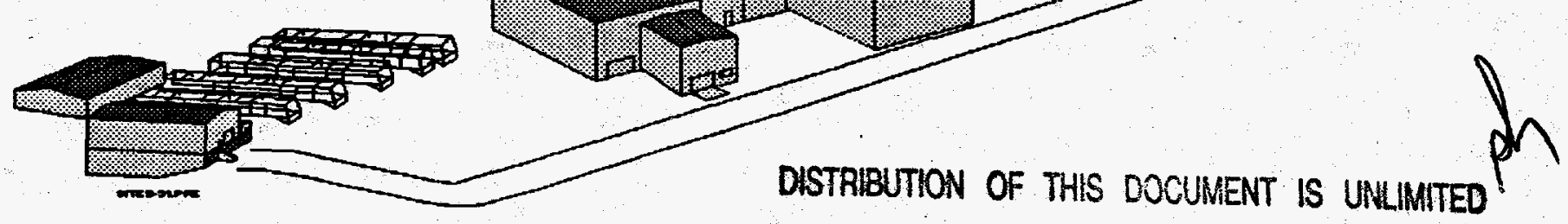

WVDP-321 MASTER

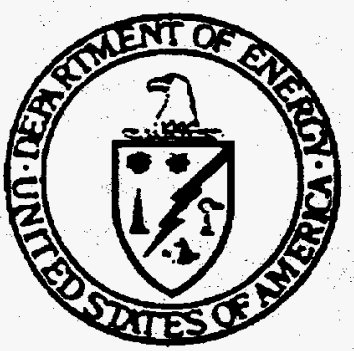

United States Department of Energy

West Valley Demonstration Project

West Valley, New York 


\section{DISCLAIMER}

This report was prepared as an account of work sponsored by an agency of the United States Government. Neither the United States Government nor any agency thereof, nor any of their employees, makes any warranty, express or implied, or assumes any legal liability or responsibility for the accuracy, completeness, or usefulness of any information, apparatus, product, or process disclosed, or represents that its use would not infringe privately owned rights. Reference herein to any specific commercial product, process, or service by trade name, trademark, manufacturer, or otherwise does not necessarily constitute or imply its endorsement, recommendation, or favoring by the United States Government or any agency thereof. The views and opinions of authors expressed herein do not necessarily state or reflect those of the United States Government or any agency thereof. 


\section{DISCLAIMER}

Portions of this document may be illegible in electronic image products. Images are produced from the best available original document. 


\section{West Valley \\ Demonstration Project}

Doc. ID Number

WVDP-321

Revision Number

0

Revision Date

$6 / 23 / 98$

Controlled copy No.

Supplement Analysis II of Environmental Impacts Resulting from Modifications in the West Valley Demonstration Project

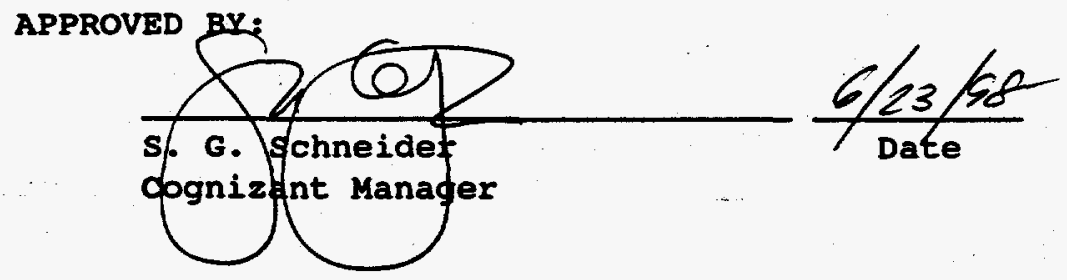

APPROVED BY:

E. D. Sayage

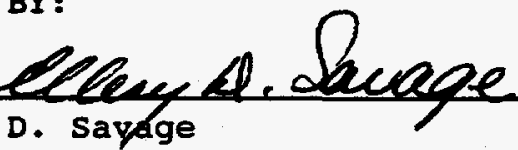

Cognizant Staff Manager

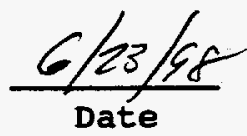

West Valley Nuclear Services Co., Inc.

P.O. Box 191

West Valley, NY 14171-0191

WV-1816, Rev. 1 
WVDP-321

Rev. 0

\section{WVNS RECORD OE REVISION}

\section{DOCUMENT}

If there are changes to the controlled document, the revision number increases by one. Indicate changes by one of the following:

- Placing a vertical black line in the margin adjacent to sentence or paragraph that was revised.

- Placing the words MAJOR CHANGE REVISION at the beginning of the text.

- Placing either FC\#> or PC\#> (whichever applies) in the left-hand margin at the beginning of the paragraph or section where the field/page change has been made AND placing a vertical black line in the margin adjacent to the actual change.

- Placing the words "New-Type Revision" or "On-Hold" in the description of changes.

Example:

The vertical line in the margin indicates a change.

FC1> The FC\#> in the margin along with the vertical line (redline) indicates a change.

\begin{tabular}{cl}
\hline Rev. No. & Description of Changes \\
\hline 0 & Original Issue \\
& This document was approved $6 / 23 / 98$ by the \\
& Ohio Field office Manager. This Supple- \\
& ment Analysis II is the 1998 (five year) \\
& update to the Final Environmental Impact \\
& Statement: Long-Term Management of Liquid \\
& High-Level Radioactive Wastes Stored at \\
& the Western New York Nuclear Service \\
& Center (DOE/EIS-0081) issued June 1982.
\end{tabular}


WVDP-321

Rev. 0

WVNS RECORD OF REVISION CONTINUATION FORM

Rev. No.

Revision on Page (s) Dated 


\section{Table of Contents}

1.0 Background and Purpose . . . . . . . . . . . . . . . . . . . . . . . . 1

2.0 Description of WVDP Processes and Modifications . . . . . . . . . . . . 5

2.1 General . . . . . . . . . . . . . . . . . . . . . . . . . 5

2.2 HLW Solidification . . . . . . . . . . . . . . . . . . . 8

2.3 Management and Interim Storage of wastes . . . . . . . . . . . . . 11

2.4 Disposal of Wastes . . . . . . . . . . . . . . . . . . . . . . . . 14

2.5 Transport of Wastes . . . . . . . . . . . . . . . . . . . . . . 18

2.6 General site operations . . . . . . . . . . . . . . . . . . . 22

2.7 Facility Decontamination . . . . . . . . . . . . . . . . . . 23

2.8 spent Nuclear Fuel (SNF) storage at the wVDP . . . . . . . . . . . 26

3.0 Environmental Impacts of WVDP Processes and Modifications . . . . . . . 29 3.1 Routine Releases . . . . . . . . . . . . . . . . . . . . . 30

3.2 Doses Due to Routine Operations . . . . . . . . . . . . . . . . . 34

4.0 summary . . . . . . . . . . . . . . . . . . . . . . . . 35 


\section{Iist of Tables}

2-1 Comparison of Original and Modified WVDP Processes . . . . . . . . . .

3-1 Comparison of Original and Modified WVDP Routine Radioactive Impacts .

a. Atmospheric.

b. Iiquid

c. Solid waste.

3-2 Operational (1982-1997) Releases of Radioactivity (in millicuries) . . .

3-3 WVDP Atmospheric Regulatory Limits . . . . . . . . . . . . . . . . . . . .

3-4 FVDP Nonradiological Liquid Regulatory Limits . . . . . . . . . . . . . .

3-5 Comparison of Original and Modified WVDP Occupational Dose Due to Routine operations (PERSON-REM)

3-6 Comparison of Original and Modified WVDP Short-Term Radiological Doses Due to Routine operation: Off-site Maximum Individual Dose (REM) . . . .

3-7 Comparison of EIS Incremental Collective Population Dose Predictions with Doses Reported in the Annual Site Environmental Reports (1982-1997) .

\section{List of Figures}

2-1 Original WVDP Process Per FEIS (DOE/EIS-0081) . . . . . . . . . . . . . .

2-2 Modified WVDP Process . . . . . . . . . . . . . . . . . . . . . . . . .

3-1 Permitted Air Discharge Points at the West Valley Demonstration Project .

3-2 Liquid Discharge Points at the West Valley Demonstration Project. . . . 
TVDP-321

Rev. 0

Page 1 of 67

CHAPTER 1.0

BACKGROUND AND PURPOSE

The West Valley Demonstration Project (WVDP) is located at the Western New York Nuclear service Center (WNYNSC) in Cattaraugus County, a rural area about $50 \mathrm{~km}$ ( 30 miles) southeast of Buffalo. The 3,345-acre WNYNSC includes a shutdown commercial nuclear fuel reprocessing plant, a spent nuclear fuel receiving and storage facility, disposal areas for solid radioactive wastes, and underground tanks containing liquid high-level radioactive wastes.

Approximately 600,000 gallons of liquid high-level radioactive waste (Huw) were placed in storage in underground tanks at the wNYNSc starting more than thirty years ago. The wastes were generated by the previous site operator, Nuclear Fuel services, Inc. (NFS) during its commercial fuel reprocessing operations (1966-1972). The tanks in which most of this waste is stored have a design life (based on standard industry practice in effect at the time) of forty years. While corrosion analysis has revealed that only limited tank degradation has taken place, the failure of these tanks could release HLW to the environment, resulting in a difficult, expensive remediation and restoration.

The U.S. Congress recognized the inherent risks of continued liquid HLW storage and in 1980 enacted the West Valley Demonstration Project Act (wVDPA), which requires the U.S. Department of Energy (DOE) to demonstrate the technology for removal and solidification of HLW. Before initiating the Project, the DOE prepared an Environmental Impact Statement (EIS) (U.S. Department of Energy June 1982 ) in accordance with both the National Environmental Policy Act (NEPA) and the WVDPA in order to assess the potential effects of the proposed actions and alternatives to those actions. The Record of Decision (ROD) to begin the solidification of liquid HLW was published in 1982 (U.S. Department of Energy September 1982).

In accordance with the ROD, the DOE is processing liquid HLW in preparation for its ultimate disposal at a federal repository. The final HLW form of borosilicate glass was selected as described in the 1983 Memorandum-to-File for High-Level Waste Form Selection (U.S. Department of Energy June 1983). The final low-level waste (LLW) form of cement is described in the Environmental Evaluation for the operation of the Cement Solidification system (U.S. Department of Energy January 1985 ). 
WVDP-321

Rev. 0

Page 2 of 67

The DOE issued the Final Environmental Impact statement (FEIS). (U.S. Department of Energy June 1982), based on the best available information, before any commitment was made to proceed with detailed design efforts or other major vitrification activities.

It was recognized that other decisions would flow from the proposed actions, such as final decontamination and decomissioning (D\&D) of WVDP facilities and location and methods of disposal for the low-level wastes associated with both solidification and final D\&D activities. In the 1982 EEIs' Foreword (p. iii), the DOE stated its intent to use a tiering approach to comply with NEPA for these future decisions.

Since the ROD was issued, certain modifications to operations/activities at the wVDP have been made in order to improve operations and mitigate potential environmental impacts. A series of Safety Analysis Reports (SARs), Environmental Evaluations (EEs), and other related NEPA documentation (Environmental Assessments (EAs), Memoranda-To-File $e^{2}$ and Categorical Exclusion determinations) have addressed such modifications. A notice of intent to prepare a second EIS (U.S. Department of Energy December 1988) was published. Currently in the draft EIS stage, the second EIS will consider the environmental impacts associated with decisions for WVDP completion and site closure.

In 1993 the DOE issued its first supplement Analysis ${ }^{3}$ (SA) of the 1982 FEIS. The SA examined the ongoing activities supporting HLW solidification as well as actions with ancillary facilities necessary for the completion of the wVD. That analysis resulted in DOE's determination that "the SA has resulted in a determination that a supplement to the 1982 Environmental Impact statement is not required." (U.S. Department of Energy september 1993).

The purpose of this second supplement analysis is to re-assess the 1982 FEIS' continued adequacy. This document provides the necessary and appropriate data for

EEs were environmental analysis documents that were prepared at the direction of DoE-Idaho to ascertain the environmental effects of actions. These documents support the NEPA process but have no standing in NEPA or the CEQ. Since the EEs were only used by DOE-Idaho, they have been discontinued as recommended in DOE Tiger Team audit findings in 1989 and Secretary of Energy Notice 15-90 (U.S. Department of Energy, Eebruary 5, 1990).

2 MTFs are DOE envifonmental analysis documents that were prepared to document proposed actions that have no significant impacts and were not listed as categorical exclusions in the DOE NEPA Guidelines. MTEs were discontinued on September 30, 1990 at the direction of sEN-15-90.

3. A Supplement Analysis is a DOE environmental analysis document used to determine whether to prepare a supplemental EIS. Supplemental EISs are required if there are substantial changes to a proposed action or if significant new circumstances or information relevant to environmental concerns emerges after an EIS is final (10CFRI021.314(a)(c)). 
WVDP-321

Rev. 0

Page 3 of 67

the DOE to determine whether the environmental impacts presented by the ongoing refinements in the design, process, and operations of the WVDP since the 1982 ROD are considered sufficiently bounded within the envelope of impacts presented in the FEIs and supporting documentation. Chapter 2 of this analysis describes the original WVDP processes and the modifications to these processes since the ROD was issued in 1982 . Chapter 3 compares the original and modified operations quantitatively. The incremental impacts of the modifications have been examined to determine whether the impacts are bounded by the analyses contained in the FEIs. Chapter 4 presents a summary.

Projects for which NEPA documentation has been approved are also subject to further DOE site-specific safety and environmental review. Operational readiness reviews, process safety analyses, hazard analyses, and environmental permitting activities are performed to ensure safe and environmentally acceptable project implementation. Each of these subsequent reviews is subject to local DoE approval prior to implementing an action.

This supplement analysis does not address those activities that are the subject of the draft EIS currently in progress (i.e., disposal of transuranic waste (TRU), disposal of Class B/C LIW, and closure and/or long-term management of Project facilities).

\section{References}

U.S. Congress. 1980. West Valley Demonstration Project Act. PL-96-368.

U.S. Department of Energy. June 1982. Final Environmental Impact Statement: Long-Term Management of Liquid High-Level Radioactive Wastes stored at the Western New York Nuclear Services Center, West Valley. DOE/EIS-0081.

- September 15, 1982. Record of Decision. Federal Register, 47 FR40705.

- June 3, 1983. Memorandum-to-File: Selection of the west valley

Demonstration Project Waste Form.

- 1985. Environmental Evaluation for the Operation of the Cement Solidification system. WVDP-037, Rev. 0 .

- December 30, 1988. Notice of Intent to Prepare an Environmental Impact Statement for Completion of West valley Demonstration Project Activities and closure of the western New York Nuclear Service Center. Federal Register, 53 FR251 p. 53052.

- February 5, 1990. Secretary of Energy Notice 15-90.

- September 24, 1993. Supplement Analysis Determination. Letter DW:93:1314, from B. A. Mazurowski to W. G. Poulson.

- 1996. Draft Environmental Impact statement for Completion of the West Valley Demonstration Project and closure or Long-Term Management of Facilities at the Western New York Nuclear Service Center. DOE/EIS-0226-D. 
WVDP -321

Rev. 0

Page 4 of 67

THIS PAGE INTENTIONALLY LEET BLANK

WVDP: 0006405.01 
WVDP-321

Rev. 0

Page 5 of 67

CHAPTER 2.0

DESCRIPTION OE WVDP PROCESSES AND MODIFICATIONS

\subsection{General}

The subject of this analysis is the DOE's continued operation of the WVDP, as modified, in order to convert the liquid HLW stored at the West valley site into a stable form for ultimate, safe disposal. The original WVDP process, as described in the 1982 EEIS, is illustrated in Figure 2-1.

At its conclusion, the WVDP process (Fig. 2-2) will have vitrified HLW stored in underground waste tanks $8 D-1,8 D-2,8 D-3$, and $8 D-4$. Tank $8 D-2$ contains a sludge composed of neutralized PUREX HLW. A supernate salt solution had originally overlain the sludge layer; the supernate was pumped from tank 8D-2 to ion exchange columns mounted in tank 8D-1 and decontaminated by ion exchange in the supernate Treatment $^{4}$ system (STS). The decontaminated supernate was then concentrated by evaporation in the Liquid Waste Treatment system (LWTS). The concentrated salt solutions were solidified in drums in the cement solidification system (CSs) and are stored on-site in the Radwaste Treatment system (RTS) Drum Cell. The water from the evaporation process was sampled and then either recycled or treated further at the Low-level Waste Treatment Facility (ILWTF) and released to the environment.

After the supernate was decontaminated, sodium hydroxide and water were added to the tank 8D-2 sludge fraction and then mixed (washed) to remove sulfate salts. The wash water was then processed in the same manner through the STS, LWTS, CSS, and the ILWTF.

The contaminated ion-exchange media from STs operations in tank 8D-1, tank 8D-2 residual high-activity sludge, and THOREX HLW transferred from tank 8D-4, were then combined in tank 8D-2 and are being transferred to the Vitrification Facility (VF), where the wastes are being immobilized in borosilicate glass and encased in stainless steel canisters.

Filled canisters are currently placed in High-Level Waste Interim Storage (HLwIS) located in the former Chemical process Cell, although a new on-site HLw interim storage facility may be constructed (as described in section 2.3). Storage will

4 The 1982 EEIS refers to the aqueous phase of the high-level waste in tank 8D-2 as "supernate" (Appendix B). Other WVDE documents refer to the aqueous phase as "supernatant." This document uses "supernate" to maintain consistency with the 1982 EEIS. 
WVDP-321

Rev. 0

Page 6 of 67

continue at West Valley until the HIW canisters are transported to another interim storage facility or to a federal repository for final disposition. Transportation to a federal repository or other DOE interim storage facility has been evaluated in the DOE's Final Waste Management Programmatic Environmental Impact statement (U.S. Department of Energy 1997).

In June 1982 the DOE issued a final Environmental Impact statement (U.S. Department of Energy June 1982) that identified four alternatives for management of liquid highlevel wastes at the WVDP: on-site processing to terminal waste form, on-site processing to interim waste form, in-tank solidification, and no action--delay for ten years or continued storage in tanks. In the Record of Decision (U.S. Department of Energy September 1982), the DOE selected on-site processing to terminal waste form as the preferred alternative for waste management.

The FEIS and ROD conceptually evaluated the proposed WVDP HLW solidification activities, including radiological and limited nonradiological impact analyses for:

1) HLW solidification, including removal of liquid HLW from the tanks, separation of sludge from the supernate, removal of residual radioactive waste from the supernate, concentration of the HLW, and conversion of the HLW into a solid terminal waste form

2) Management and storage of wastes, including construction of temporary storage facilities, packaging and handling of these wastes, and operation of the LLW Treatment Facility

3) Disposal of waste, including disposal of HLW tanks, on-site disposal of LLW and nonradioactive rubble, regional disposal of LLW, and disposal of HLW and transuranic (TRU) wastes at a federal repository

4) Transport of $\mathrm{HLW}$ and TRU waste to a federal repository and LLW to an offsite regional facility

5) General site operations, including use and modification of existing facilities, construction of new facilities, use of land and utilities, upgrades to existing roads and rail spur, and security

5 As defined in the 1982 EEIS (p. 2-5) and this Supplement Analysis, transuranic (TRU) wastes are non-high-level wastes that contain more than 10 nanocuries of transuranic elements (isotopic numbers $>92$ ) per gram of wastes.

WVDP: 0006405.01 
WVDP-321

Rev. 0

Page 7 of 67

6) Decontamination of the process cells before solidification start-up, and final decontamination, dismantling, and decommissioning of facilities at the end of the West Valley Demonstration Project.

The NEPA determination for selection of the HLW form was issued by the DOE in May 1983 (U.S. Department of Energy July 1982). The DOE adopted a Savannah River Environmental Assessment (U.S. Department of Energy October 1982), which analyzed the potential environmental consequences of selecting borosilicate glass as the immobilized HLW form.

DOE's 1986 Environmental Assessment (U.S. Department of Energy 1986) documented the WVDP finding of no significant impact (FONSI) for a proposal to dispose of the Project's LIW on-site. As a result of ensuing litigation and a stipulation of Compromise settlement (U.S. District Court 1987), on-site disposal of ILW was deferred pending the issuance of the record of decision for the EIS for wVDP completion and site closure (U.S. Department of Energy 1996). The DOE may, however, dispose of Class $A$. IIW in accordance with applicable law at a location other than the WNYNSC.

Modifications to the 1982 FEIS processes made since 1982 include improvements in sludge/supernatant treatment techniques, improvements in the LLW wasteform, and improvements in vitrification technology. Modifications to wvp operations resulted in increased on-site storage of LLW (because of the stipulation of compromise settlement), increased site population and attendant facilities/services, and continued storage of spent nuclear fuel.

A summary comparison of the original and modified WVD operations is found in Table 2-1. Process diagrams for the original processes (as described in the 1982 FEIS) and modified (as operating) processes are shown in Figures 2-1 and 2-2 respectively. The process modifications are described in more detail in the following sections.

\section{References}

U.S. Department of Energy. June 1982. Final Environmental Impact Statement, Long-Term Management of Liquid High-Level Radioactive Wastes stored At The Western New York Nuclear Service Center, West Valley. DOE/EIS-0081.

- July 1982. Environmental Assessment, waste Form Selection for SRP High Level Waste, Savannah River Plant Aiken, S.C. DOE/EA-0179.

- September 15, 1982. Record of Decision. Federal Register, 47 FR40705.

WVDP: 0006405.01 
WVDP-321

Rev. 0

Page 8 of 67

- June 3, 1983. Memorandum-To-File: Selection of the West Valley

Demonstration Project Waste Form.

DOE/EA-0295.

1986. Environmental Assessment for Disposal of Project Low-Level Waste.

U.S. Department of Energy. 1996. Draft Environmental Impact statement for Completion of the West Valley Demonstration Project and Closure or Long-Term Management of Facilities at the Western New York Nuclear service Center. DOE/EIS-0226-D.

- 1997. Final Waste Management Programmatic Environmental Impact statement for Managing, Treatment, storage, and Disposal of Radioactive and Hazardous waste. DOE/EIS-0200-F.

Ues. District Court. May 1987. Stipulation of Compromise Settlement (8601052-C).

\subsection{HI Solidification}

\section{EFIS Process Description}

The FEIS for the WVDP (U.S. Department of Energy June 1982) described the process planned for treating the acidic THOREX wastes, recovering radionuclides from the PUREX tank supernate, and treating the neutralized PUREX tank sludge. The reference case for the final HLW form was borosilicate glass, although the final decision to use this waste form was not made until after issuance of the FEIs (U.S. Department of Energy June 1983). The acidic THOREX wastes were to be removed from the tank and processed directly into glass. The neutralized PUREX wastes, which consisted of an alkaline supernate with a very high dissolved-salt content that overlay an alkaline sludge, were to be mixed in the tank and pumped to the process building where the sludge would be separated from the supernate. The supernate would then be passed through ion-exchange resin columns to be stripped of cesium isotopes (decontamination factor $[D F]=10^{2}$ ). The eluate from these columns and the washed sludge would be fed to a spray calcinator and then to melter equipment to produce the vitrified waste form, i.e., high-level waste immobilized in borosilicate glass.

Liquid HLW would be atomized in the spray calcinator. Reaction products (water, nitric acid, and oxides of nitrogen) would pass through sintered stainless steel filters and be routed to an off-gas treatment system. Most of the tritium would pass into the off-gas as tritiated water vapor. The balance of the radionuclides would remain in the calcine, which would be mixed with glass frit, melted into glass, and poured into steel canisters. A total of approximately 300 canisters would be formed (U.S. Department of Energy June 1982). 
WVDP- 321

Rev. 0

Page 9 of 67

FEIS section B.1.3.3, Removal of Neutralized Wastes from Tank 8D-2, indicates that removal of the HLW from tank 8D-2 would require additional efforts to remove "the residual sludge or heel." Use of clean water dilution, sluicing, and vacuun devices to remove residual solids as well as acids or solvents to decontaminate the empty HLW tanks was also envisioned (FEIS section B.1.3 [p. B-11, 14] and Section 2.1.1.1 [p. 2-5]).

As described in section 4.1.6 of the 1982 FEIS, Short-Term Radiological Impacts, the worst-case scenario for release of radioactive materials into the environment and the bounding incident for the entirety of the wVDP (although remote) is dispersal of liquid HLW following a plane crash into the storage tanks, resulting in a calculated dose of $3 \times 10^{4}$ rem to the "maximum exposed hypothetical individual" and $5 \times 10^{\circ}$ person-rem to the population through external exposure to radionuclides deposited on the ground and through inhalation (U.S. Department of Energy June 1982 ).

\section{Modified-Process Description}

After selecting the preferred alternative in the Record of Decision (RoD), a series of safety analysis reports (SARs) and environmental evaluations (EEs) were prepared that described the modified and improved HLW solidification process that would be used. The spray calcinator step was eliminated. The acidic THorEx waste from tank 8D-4 was combined with cesium and strontium-saturated ion-exchange media (zeolite) from tank 8D-1, PUREX sludge in tank 8D-2, and glass formers before transfer to the vitrification facility's ceramic melter for solidification. The continuous melter requires simpler equipment than a spray calcinator, improves mixing of feed with additives, and results in reduced off-gas emissions.

pretreatment of the PUREX waste was accomplished between 1988 and 1990 using a specially designed, four-step processing system (described in section 2.1) illustrated in Figure 2-2. Pretreatment removed 5,209,000 curies of radioactivity (primarily cesium) and the salts and sulfates that would have compromised the quality of the waste glass (West Valley Demonstration Project 1998).

Liquids (supernate) were first processed through ion-exchange columns filled with zeolite to adsorb the cesium. Then an evaporator concentrated the resulting lowlevel liquid waste containing salts and sulfates. The concentrated liquid was blended with cement and poured into 71-gallon $(270-L)$ square, plastic-lined steel drums. The project completed the processing of 1.4 million gallons (5 million $\mathrm{I}$ ) of liquid in May 1995, producing nearly 20,000 drums of cemented waste (West valley Demonstration Project september 26, 1997).

WVDP : 0006405.01 
WVDP-321

Rev. 0

Page 10 of 67

After pretreatment of the liquid was complete, the layer of sludge on the bottom of tank 8D-2 was repeatedly washed. The washwater was processed just as the PUREX supernate, but used a titanium oxide-treated zeolite for ion-exchange. Nearly 767,000 gallons $(2.9$ million $L)$ of wash water were treated, storing more than 1 million curies of radioactivity in the zeolite (West Valley Demonstration Project september 26, 1997). The cesium-laden zeolite was discharged from the ion-exchange columns in tank 8D-1 to the tank itself. Most of the zeolite in tank 8D-1 was transferred to tank $8 D-2$ in 1996 as a final step before vitrification. This material proved to be an important component of the waste feed for the vitrification process, comprising 178 of the glass composition.

Upon completion of integrated testing and DOE Operational Readiness Reviews of the vitrification system, the Project began high-level waste processing on.June 24, 1996. A mixture of tank 8D-2 PUREX sludge, acidic THOREX wastes, zeolite, and glass formers continue to be fed to the vitrification melter to make the high-level waste glass. As of December 31, 1997, a total of 178 stainless steel canisters had been filled with high-level waste/glass, effectively stabilizing more than 15 million curies of radioactivity (65\% of waste) (West Valley Demonstration Project 1998).

After the initial HLW liquid processing, the vitrification facility will process the HLW tank residual high activity waste (HLW tank heels). Planning and preparatory work is currently under way and HLW tank heel vitrification will be performed after the initial HLW vitrification processing campaign is completed.

\section{References}

U.S. Department of Energy. June 1982. Final Environmental Impact Statement: Long-Term Management of Liquid High-Level Radioactive Wastes Stored at the Western New York Nuclear Service Center, West Valley. DOE/EIS-0081.

. June 3, 1983. Memorandum-To-File; Selection of the West valley Demonstration Project Waste Form.

West Valley Demonstration Project. September 26, 1997. Vitrification Success Story The West Valley Demonstration Project Setting a world-class standard in Radioactive Waste Management.

- 1998. West Valley Demonstration Project - Safely Turning Radioactive Liquid Into a Manageable Solid Glass (Information Press Release). 
WVDP-321

Rev. 0

Page 11 of 67

\subsection{Management and Interim Storage of Wastes}

EEIS Process Description

The management and interim storage of wastes, as described in the 1982 FEIs, called for the decontaminated supernate (considered to be LLW) to be evaporated and the solids converted to a salt cake (22\% residual water) that would be stored in approximately 5,100 standard 55-gallon (208-I) steel drums $\left(\sim 37,000 \mathrm{ft}^{3} / \sim 1050 \mathrm{~m}^{3}\right)$ (U.S. Department of Energy June 1982). The concentration of fission products in the salt cake was estimated to be $2 \mu \mathrm{Ci} / \mathrm{g}$ and that of the actinides to be $0.4 \mathrm{nci} / \mathrm{g}$ (FEIS p. B-26). These, along with miscellaneous LIW and TRU wastes $\left(\sim 100,000 \mathrm{ft}^{3}\right)$, would be temporarily stored on-site in a new, temporary, below-grade facility until a burial ground became available.

Radiological impacts associated with the handling and storage of HLW at West Valley were identified and described in section B.4.4.1 of the 1982 FEIS. The assessment for handling the HLW identified the following activities: (1) placing the HLW canisters onto a vehicle for on-site transport to an on-site HLw storage facility; (2) unloading the canisters from the vehicle and placing them in the temporary HLW storage facility; and (3) retrieving the canisters from storage and loading them onto transport vehicles for shipment off-site.

The FEIS indicates that potential scenarios leading to the release of radionuclides from accidents during the interim storage of processed HLW at the WVDP were considered. However, the contributions from such accidents to the total radiological risk of the Project were so small (<0.1\% of the total short-term risk) that a specific discussion of such events was not warranted (FEIS section H.2.2.2 [p. $\mathrm{H}-18]$ ).

No doses were calculated for normal storage operations because no releases were anticipated in the FEIS. The worst-case scenario for release in terms of radiation dose to the public was calculated for a catastrophic storage accident. such an accident could lead to a dose to the maximally exposed individual of 20 rem and $3 \times 10^{5}$ person-rem to the general population. However, the probability of the occurrence of this accident is so low $\left(1 \times 10^{-8}\right.$ per year) that, in spite of the magnitude of the potential release, the overall risk is minor. Impacts from the continued storage of spent fuel were not considered. Although impacts associated with TRU waste storage are calculated, the length of storage for TRU was assumed to be 15 years.

WVDP : 0006405.01 
WVDP-321

Rev. 0

Page 12 of 67

Section 2.2 of the FEIS indicated that the $300 \mathrm{HLW}$ canisters anticipated to be generated at the completion of vitrification processing would be stored on-site in a new temporary storage facility or in modified existing facilities. Appendix B, section 3.1.4, of the FEIS provides conceptual design and details regarding the anticipated impacts from the new facility (U.S. Department of Energy June 1982).

\section{Modified-Process Description}

The decontaminated supernate and sludge wash solutions were processed in two distinct steps. First the decontaminated supernate and sludge wash solutions were evaporated to approximately $40 \%$ solids and $20 \%$ solids respectively (by weight) in the LWTS. Condensate from the LWTS (evaporator overheads) was further decontaminated by ionexchange in the LIWTF and either recycled or discharged to the environment.

secondly, the concentrated salt solution (evaporator bottoms) was cement-solidified into 71-gallon drums (270-I) in the cement solidification system (Css). Approximately 20,000 drums $\left(\sim 183,000 \mathrm{ft}^{3} / \sim 5,200 \mathrm{~m}^{3}\right)$ were generated in this manner (west valley Nuclear services Co., Inc. September 26, 1997), with about 8,000 being Class $A$ ILW and the remainder class $C$ LLW (West Valley Nuclear services Co., Inc. 1998). The drums are being stored temporarily in an above-grade storage facility (Radwaste Treatment system [RTS] drum cell). The class A drums may be shipped offsite in the near future for disposal but the class $c$ wastes will continue to be stored in the RTS drum cell pending the Record of Decision (ROD) for the Environmental Impact statement for Completion of the West Valley Demonstration Project and Closure or Long-Term Management of Facilities at the Western New York Nuclear service Center (U.S. Department of Energy 1996).

The WVDP currently stores approximately, 320,000 $\mathrm{ft}^{3}\left(9,000 \mathrm{~m}^{3}\right.$ ) of Class $\mathrm{A} \mathrm{LLW}$ (West Valley Nuclear services Co., Inc. 1996), of which approximately $1 \frac{8}{8}-28$ is a mixed waste (both radioactive and hazardous (as defined by the Resource conservation and Recovery Act]). The waste is handled, packaged, and stored as part of preparations for vitrification, facility maintenance, environmental monitoring, and ancillary support system operations. In addition to the LLW in storage, the WVDP estimates that an additional $18,000 \mathrm{ft}^{3}\left(500 \mathrm{~m}^{3}\right)$ of Class A LLW per year will require management (West valley Nuclear services Co., Inc. 1996). The majority of this waste was generated during activities preparing for vitrification and routine maintenance of the main plant and facilities. These wastes are stored in temporary structures and facilities constructed to meet ongoing waste management needs.

WVDP: 0006405.01 
WVDP -321

Rev. 0

Page 13 of 67

To manage the wastes generated by initial decontamination, maintenance, operations, and construction, and to lessen the burden of ongoing waste storage, the wVDP continues to construct and operate waste management facilities as identified in the FEIS. (See Section 3.3.2 in West Valley Nuclear services Co., Inc. 1997.)

The Contact Size-Reduction Facility (CSRE) is used to size-reduce and decontaminate large, contact-handled vessels, piping, and other equipment. Located next to the CSRF cutting room are two decontamination facilities. One facility is a walk-in spray booth where large items can be washed down. The second facility is a Liquid Abrasive Decontamination system (LADS). A lag storage building was erected in 1984 for the storage of contact-handled waste packages. The Chemical Process Cell - Waste Storage Area (CPC-WSA) was-constructed in 1985 to store the higher activity materials resulting from initial decontamination activities in the plant. Two additional structures (Lag storage Areas \#1 and \#2 (LSAs)) were constructed in 1987 and 1988 to accommodate the storage of packaged LLW; in 1991, ISA \#3 and LSA \#4 were constructed to handle similar wastes. The WVDP also built a container sorting and Packaging Facility (CSPF) within LSA \#4 in 1995 for the sorting, volume reduction, and repackaging of ILW prior to off-site shipment. The DOE is currently evaluating the future need for a staging facility for the shipout of contact-handled waste. The DOE is currently planning to construct and operate a Remote-Handled waste Facility (RHWF) in order to effectively perform similar waste management activities for higher activity wastes. The RHWF would provide facilities for the receiving, inspecting, assaying, size-reducing, decontaminating, repackaging, and surveying of wastes and waste containers that cannot be handled directly. Examples of these types of materials are equipment removed from the old process cells (e.g.; Chemical Process Cell equipment) and expended vitrification equipment. Following repackaging, the wastes will either be sent off-site or to existing on-site storage facilities. As indicated in Chapter 1, projects such as the RHWF would receive further local DOE review such as safety analysis review, hazard classification, environmental permits, and operational readiness review prior to implementation.

As of December 31, 1997, 178 canisters had been filled with HLW (West Valley Nuclear Services Co., Inc. 1998). These canisters are currently in storage racks in the High-Level Waste Interim storage (HLWIS) that is located in the former Chemical Process Cell (CPC). These canisters may be stored in the HLwIS, stored in a new onsite HLW storage facility similar to the one described in section B.3.1.4 of the 1982 FEIS, or shipped to another DOE site for interim storage until the opening of a federal repository. (See section 7.2.3, 9.1.2.4, 9.2.2, and 9.3.3 in the Final Waste Management Programmatic Environmental Impact statement for Managing, Treatment, Storage, and Disposal of Radioactive and Hazardous Waste [U.S. Department of Energy

WVDP: 0006405.01 
WVDP-321

Rev. 0

Page 14 of 67

19971). The repository is currently projected to be available for HLw disposal by 2015. Modifications to the HLW load-in facility in preparation for HLW load-out, including construction and installation of equipment, would be required.

\section{References}

U.S. Department of Energy. June 1982. Final Environmental Impact Statement: Long-Term Management of Liquid High-Level Radioactive Wastes stored at the Western New York Nuclear Service Center, West Valley. DOE/EIS-0081.

- 1996. Draft Environmental Impact Statement, Long-Term Management of Iiquid High-Level Radioactive wastes stored at the Western New York Nuclear Service Center, west Valley. DOE/EIS-0226-D.

- 1997. Final Waste Management Programmatic Environmental Impact statement for Managing, Treatment, Storage, and Disposal of Radioactive and Hazardous Waste. DOE/EIS-0200-F.

West Valley Nuclear Services Co., Inc. 1996. Retransmittal of Environmental Checklist OH-WVDP-96-01, I. C. Salvatori to T. J. Rowland. Letter WD:96:0697.

- September 26, 1997. Vitrification success Story - The West Valley

Demonstration Project Setting a World-class standard in Radioactive waste Management.

1997. Annual Waste Management Plan. WVDP-019. Rev.15.

- May 1, 1998. Information to support the supplement Analysis to DOE/EIS0081, Bill Champion to M. F. McGarry and W. T. Watters. Letter CA:98:0068.

- 1998. West Valley Demonstration Project - Safely Turning Radioactive Liquid Into a Manageable Solid Glass (Information Press Release).

\subsection{Disposal of Wastes}

\section{FEIS Process Description}

The canisters generated during the HLW processing were assumed to be stored on-site in either a modified portion of the plant or in a new facility until the availability of a federal repository. FEIS section 2.1 .1 and 4.3 .3 assumed the repository would be available by 1997. The HLW would be shipped to the repository via special railcar (see p. 2-3 and p. 2-5 in the FEIS [U.S. Department of Energy June 1982]) for permanent disposal. Section 1.5 .2 of the 1982 FEIS describes how NEPA requirements would be met for the national program for HLW management. The impacts associated with the location and design of the federal repository were considered in a separate DOE NEPA document for the national HLW management program.

DOE's FEIS assumed that the federal TRU repository would be located approximately 3,000 miles $(4,800 \mathrm{~km})$ from the WVDP, would be of a deep geologic type, and would be available in 1997. (See p. 2-5 in the FEIS [U.S. Department of Energy June 1982].) 
WVDP -321

Rev. 0

Page 15 of 67

The FEIS assumed that all packages used for the disposal of the TRU wastes would be overpacked for transport and disposal. (See p. B-82 in the FEIS [U.S. Department of Energy June 1982].) Table B.24 of the FEIS gives the long-term $(>10,000$ yrs) population risks resulting from disposal of TRU wastes in a federal repository.

Page 2-5 of the FEIS indicates DOE's assumption that "there would also be a large volume of non-high-level radioactive wastes generated as a result of project activities." For purposes of bounding potential LLW disposal impacts, it was assumed in the 1982 FEIs that ultimate disposal of LLW would be in a regional burial ground (FEIS p. 2-5). On-site disposal in the existing NRC-licensed disposal area (NDA) was also evaluated (FEIS P. 1-4). Section B.5 indicated that LLW generated from the HLW solidification process was to be "transported via trucks in about 1,700 shipments to a regional burial ground for permanent disposal" U.S. Department of Energy June 1982). The wastes were to be contained in 55-gallon (208 L) steel drums and boxes.

The discussion of disposal impacts in the FEIS was limited to HLW, TRU, and LLW. specific environmental impacts of the generation, storage, transportation, or disposal of hazardous or mixed waste were not analyzed as these waste streams were not recognized discretely in the FEIS. However, the 1982 FEIS (p. 1-6) did commit to complying with appropriate federal and state laws, regulations, and Executive orders including, but not limited to, the Hazardous Materials Transportation Act and the Resource Conservation and Recovery Act of 1976 (U.S. Department of Energy June 1982 ).

\section{Modified-Process Description}

As stated above, the FEIS evaluated disposal of the HLW in a federal repository that was assumed would be available in 1997. The HLW repository is currently projected to receive HLW for disposal in 2015. This activity may require additional NEPA review.

The Waste Isolation Pilot Plant (WIPP) has been built by DOE to provide disposal for defense-related TRU wastes (U.S. Department of Energy November 1996). The DOE's Record of Decision to dispose of transuranic waste at wIPP was published in early 1998 (U.S. Department of Energy January 1998).

WIPP currently has no plans to accept WVDP TRU waste (U.S. Department of Energy November 1996). However, if legislative changes allowed WVDP TRU wastes to be accepted at WIPP, the waste forms and packaging described in the 1982 FEIS would meet the WIPP waste acceptance criteria. Even though the WVDP can not ship to WIPP for disposal (West valley Nuclear services Co., Inc. February 28, 1998), the wVDP may 
WVDP-321

Rev. 0

Page 16 of 67

ship TRU wastes to another facility for interim storage (i.e., Oak Ridge Reservation, Idaho National Engineering and Environmental Laboratory, Savannah River site, and/or Hanford). This activity may require additional NEPA review.

Between 1982 and 1986, the WVDP disposed of approximately $200,000 \mathrm{ft}^{3}\left(5,600 \mathrm{~m}^{3}\right) \mathrm{of}^{2}$ LLW in the NRC-licensed Disposal Area (NDA) (West Valley Nuclear Services Co., Inc. 1995). A 1986 Environmental Assessment (EA) (U.S. Department of Energy 1986) documented the DOE's finding of no significant.impact (FONSI) for its proposal to expand its disposal of LLW in the NDA. As a result of litigation and a stipulation of Compromise (U.S. District Court May 1987), on-site disposal of ILW was deferred pending the issuance of an EIS. The DOE reserved the right to dispose of Class $A$ LLW in accordance with applicable law at a location other than the WNYNSC. Disposal of Class B/C wastes has been evaluated in the draft EIS for WVDP completion and site closure (U.S. Department of Energy June 1996).

In October 1996 DOE approved the commercial off-site disposal of $245,000 \mathrm{ft}^{3} 17,000$ $\mathrm{m}^{3}$ ) of Class A LIW under a categorical exclusion (U.S. Department of Energy December 1996).. As of october 1997 a total of $5,777 \mathrm{ft}^{3}\left(164 \mathrm{~m}^{3}\right)$ of waste had been shipped or prepared for shipment for energy recovery, volume-reduction, and disposal (West Valley Nuclear Services Co., Inc. October 8, 1997). The analysis (Appendix 5, Section B.5) of off-site disposal of Class A LIW at a regional disposal facility in the FEIS and the re-analysis of LLW disposal at a remote facility in the 1986 EA quantified the impacts of the disposal of these Project-generated wastes. DoE will also dispose of an estimated $35,000 \mathrm{ft}^{3}\left(990 \mathrm{~m}^{3}\right)$ of Class A ILW as a result of decontamination and demolition of the old LLWTF.

DOE's current treatment capacities and preferred technologies for treating and disposing of mixed waste are identified in the wVDP site Treatment Plan (West Valley Nuclear services Co., Inc. 1998). As of December 1997, there were approximately $6,500 \mathrm{ft}^{3}\left(185 \mathrm{~m}^{3}\right)$ of mixed waste at the WVDP. In addition, there is an undetermined amount of mixed waste in two high-level waste streams (West Valley Nuclear Services Co., Inc. February 11, 1998). The DOE intends to dispose of West Valley mixed waste either directly at off-site disposal facilities or after off-site treatment.

Because the waste classification was not defined until after the 1982 FEIS was issued, environmental impacts related to the disposal of mixed waste were not specifically addressed in the FEIS. The mixed waste management methods employed at the WVDP are consistent with the methods proposed and analyzed in the DOE's Waste Management Programmatic Environmental Impact statement. (See section 6.2 .3 in the Programmatic EIS [U.S. Department of Energy 1997].) 
WVDP-321

Rev. 0

Page 17 of 67

Hazardous wastes are generated at the WVDP by various routine operations. The DOE uses permitted transportation services to transport the wastes to off-site treatment/disposal facilities. Between 1993 and 1996, 209 tons of hazardous waste were sent off-site for recycling or disposal at several licensed treatment, storage, and disposal (TSDs) facilities (Annual site Environmental Reports 1990-1998).

Evaluation of environmental impacts related to the off-site disposal of hazardous waste is not specifically addressed in the FEIs although necessary compliance with RCRA was recognized. This activity has been evaluated in the DOE's Programmatic Waste Management EIS (U.S. Department of Energy 1997) where the preferred alternative for the treatment of non-wastewater hazardous waste is the continued use of commercial facilities.

\section{References}

Resource Conservation and Recovery Act. 42 U.S.C. 9601 et seq. Section 3021 (b).

U.S. Department of Energy. June 1982. Final Environmental Impact Statement, Iong-Term Management of Liquid High-Level Radioactive Wastes stored At The Western New York Nuclear Service Center, West Valley. DOE/EIS-0081.

- 1986. Environmental Assessment For the Disposal of Project Low-Ievel Waste. DOE/EA-0295.

November 1996. Waste Isolation Pilot Plant Disposal Phase Draft

Supplemental Environmental Impact statement. DOE/EIS-0026-FS2 (SEIS II).

December 9, 1996. Class A Low-level waste (LIW) off-Site shipment. Letter DW:96:1033 from B. A. Mazurowski to W. G. Poulson.

- 1996. Draft Environmental Impact statement for Completion of the West Valley Demonstration Project and Closure or Long-Term Management of Facilities at the Western New York Nuclear Service Center. DOE/EIS-0226-D.

- 1997. Final Waste Management Programmatic Environmental Impact statement for Managing, Treatment, storage, and Disposal of Radioactive and Hazardous Waste. DOE/EIS-0200-E.

U.S. Department of Energy. January 23, 1998. Record of Decision for the Department of Energy's Waste Isolation Pilot Plant Disposal Phase. Federal Register, Vol. 63, No. 15 .

U.S. District Court. May 1987. Stipulation of Compromise settlement (86-1052-C).

West Valley Nuclear Services Co., Inc. June 23, 1985. Characterization Report for the NRC Licensed Disposal Area. WVDP-EIS-021, Rev. 1.

1997. Vitrification Success story - The West Valley Demonstration

Project Setting a World-class standard in Radioactive Waste Management.

- October 8, 1997. Completion of Milestone C-12, "Low-level Waste (LLW)

off-Site Shipment." Letter WD:97:0348, P. S. Klanian to T. J. Rowland.

299, Rev. 0 .

February 11, 1998. Site Treatment Plan Fiscal Year 1997 Update. WVDP-

- February 28, 1998. Annual Waste Management Plan. WVDP-019, Rev. 15.

WVDP:0006405.01 
WVDP-321

Rev. 0

Page 18 of 67

\subsection{Transport of Wastes}

\section{FEIS Process Description}

Section B.5, Transportation, of the 1982 FEIS reviews the off-site shipment of wastes, including the methods of shipment, the rules and regulations affecting the transportation of radioactive materials, the packaging, shipment parameters, truck and rail routes near the WVDP, and the environmental and radiological impacts associated with waste transportation from the WVDP (U.S. Department of Energy June 19821 .

Section 4.2.1.4, Transportation Impacts, in the FEIS (p. 4-46 to 4-48) assesses the nonradiological impacts that would occur from the transport of any type of cargo. The sources of these impacts would be the diesel fuel burned in truck and train engines, the dust generated by vehicular movement, and the likelihood of accidents.

The FEIS assumed the HLW would be transported exclusively by rail in about 40 shipments in special railcar casks to a federal repository assumed to be located 3,000 miles (4,800 kilometers) from the WVDP (p. 4-46 to 4-48) when it became available for permanent disposal (p. 2-5). The 1982 FEIS (p. 4-14) assumed no radioactive releases associated with HLW shipments.

The radiological impacts from routine transportation of HLW were sumarized in Table B.31 in the FEIS. The occupational dose due to radiation impacts for transportation of HLW as part of the preferred alternative (i.e., vitrification) was estimated to be less than one person-rem. The collective (population) dose, due to normal transportation of HLW, was 66 person-rem. These impacts were generally less than similar results for analyses of truck transport of HLW because truck transport would require many more shipments. The nonradiological impacts of rail transport of HLW were summarized in Tables B.33, B.34, and B.35 in the FEIS. Pollutant concentrations were determined to be well below primary regulatory standards. The risk of deaths and injuries due to transportation of HLW (p. B-94) was estimated to be 1.0 deaths and 0.08 injury for all shipments. (p. B-94).

The Department of Energy Headquarters office of Environmental Management (DOE-HQ/EM) or the Office of Civilian Radioactive Waste Management (OCRWM) would develop and provide required HLW shipping casks, pertinent licensing, certification, and appropriate funding to support HLW canister-removal from the WVDP, including transportation to an alternate storage facility if one became available. 
WVDP -321

Rev. 0

Page 19 of 67

The TRU wastes generated during presolidification decontamination, waste treatment, and during the final decontamination and decommissioning of the facilities would be temporarily stored in a new storage facility until a federal burial ground became available. The FEIS assumed approximately 600 truck shipments of TRU waste would be made to a federal repository located 3,000 miles (4,800 kilometers) from west Valley (p. 4-47). Transportation routes in the West Valley vicinity for truck and rail shipments were analyzed."Specific long distance routes were not analyzed because the destination for TRU waste disposal was not known (p. B-84).

The FEIS analysis assumed that 1,700 truck shipments of LLW would be made to a regional burial ground located 400 miles (640 kilometers) from West Valley. It was assumed that a permanent disposal site would be available in 1990 (p. 2-5). The FEIS assumed no radioactive releases associated with LLW shipments by rail or truck (p. 414).

The FEIS did not include a specific analysis to evaluate the impacts associated with the transportation of mixed waste, hazardous wastes, or industrial wastes. However, the FEIS committed the WVDP to compliance with appropriate federal and state laws, rules, and regulations and Executive orders including, but not limited to, the Hazardous Materials Transportation Act, the Resource Conservation and Recovery Act of 1976, and Executive Order 12088, Federal Compliance with Pollution Control standards (p. $1-6$ and $E-1$ ).

\section{Modified-Process Description}

While modifications to HLW processing were undertaken subsequent to adoption of the FEIS and issuance of the ROD, no substantive changes to the waste transportation activities have taken place. The HLW and TRU wastes are still destined for a federal geologic repository, although interim storage at a different DoE facility is being considered.

Although the 1982 FEIS assumed the HIW would be shipped exclusively by rail, the DOE's Final Waste Management Programmatic EIS (U.S. Department of Energy 1997) assessed the transportation impacts from the shipment of the HLW canisters using both truck and rail (Chapter 9, section 9.2.4). The FEIs also assessed transporting the HLW to another DOE facility for interim storage (consolidation of HLW management activities at another DOE facility).

WVPP : 0006405.01 
WVDP-321

Rev. 0

Page 20 of 67

It is estimated there may be more than 300 canisters upon completion of the solidification demonstration process at West Valley (West Valley Nuclear services Co., Inc. 1998). These canisters will either remain on-site (in the HLwIS or a new facility as described previously in section 2.31 until the federal repository is available or be shipped to another DOE facility for interim storage until the repository is open. As assumed in the 1982 FEIS (p. 2-5), the HLw will ultimately be shipped to the federal repository, which is assumed will be open in 2015 . (See p. 9-2 in the Final Waste Management Programmatic Environmental Impact statement for Managing, Treatment, storage, and Disposal of Radioactive and Hazardous Waste IU.S. Department of Energy 1997j).

Appendix E of the Final Waste Management PEIS (U.S. Department of Energy 1997) includes a transportation risk assessment for the WVDP HLW and indicates that no casks for shipping HLW canisters by truck or rail have yet been certified by the NRC (Section 9.1 .3 .3$, p. 9-11).

As stated previously in section 2.3, Management and Interim storage of wastes, interim storage of TRU waste at a location other than West valley is being considered. Transportation risks associated with transport of the West Valley TRU waste were quantified in the 1982 FEIS and were based on containers and shipment parameters described in Tables B.26 and B.27 of the 1982 FEIS.

In 1995, the DOE issued an Environmental Assessment (EA) (U.S. Department of Energy 1995) and FONSI for the commercial treatment of class A LLW and mixed low-level waste generated at the WVDP. The EA covered all aspects of the action including sorting, repacking, loading of the wastes at the WVDP, transportation of the waste, commercial treatment, and return shipment of the residual waste to the WVDP for interim storage. There is approximately $6,500 \mathrm{ft}^{3}\left(185 \mathrm{~m}^{3}\right)$ of mixed waste currently stored at the wVDP (West valley Nuclear services Co., Inc. 1998). As stated previously in section 2.4, during 1997 WVDP ILW was transported for treatment and/or disposal.

New classifications of waste have been defined since the FEIS. These include the designation of greater-than-class C (GTCC) and mixed low-level waste. Examples of potential greater-than-Class C (GTCC) waste at the WVDP include boxes of waste in the Chemical Process Cell Waste storage Area, and drums of WVDP-generated waste stored in the lag storage building and lag storage additions. Decisions regarding transportation and long-term management of GTCC wastes will be made based on the upcoming project Completion and site closure FEIs for West Valley (U.S. Department of Energy January 1996). 
WVDP-321

Rev. 0

Page 21 of 67

RCRA-regulated hazardous wastes are currently generated in small quantities and shipped off-site for recycling, treatment, and disposal. The annual amount shipped off-site varies. Evaluation of environmental impacts related to the off-site transportation of hazardous waste is not specifically addressed in the FEIs although necessary compliance with RCRA was recognized. This activity has been evaluated in the DOE's Programmatic Waste Management EIS (U.S. Department of Energy 1997) where the preferred alternative for the treatment of non-wastewater hazardous waste is the continued use of commercial facilities.

Approximately $200,000 \mathrm{lb}(90,000 \mathrm{~kg})$ of WVDP industrial waste is annually shipped off-site (west Valley Nuclear services Co., Inc. February 1998). Current industrial waste disposal practice assumes disposal at sites less than $360 \mathrm{miles}$ (580 km) from the WVDP.

\section{References}

U.S. Department of Energy. June 1982. Final Environmental Impact Statement: Long-Term Management of Liquid High-Level Radioactive wastes stored at the Western New York Nuclear Service Center, West Valley. DOE/EIS-0081.

- 1995. Environmental Assessment for the Treatment of Class $A$ LLW and MW Generated at the WVDP. DOE/EA-1071.

- January 1996. Draft Environmental Impact statement for Completion of the West Valley Demonstration Project and Closure of Long Term Management of Facilities at the Western New York Nuclear Service Center. DOE/EIS-02260-D.

- 1997. Final Waste Management Programmatic Environmental Impact Statement For Managing Treatment, storage, and Disposal of Radioactive and Hazardous Waste. DOE/EIS-0200-F.

West Valley Nuclear Services Co., Inc. June 1998. DRAFT WVDP Site Environmental Report for Calendar Year 1997.

- 1998. CY 1997 - Waste Reduction Status Report. Letter CP:98:0010.

1998. Site Treatment Plan. WVDP-299, Rev. 0, p. 3.

WVDP:0006405.01 
WVDP-321

Rev. 0

Page 22 of 67

\subsection{General site operations}

\section{EEIS Process Description}

Section 2.1.1 of the FEIS (U.S. Department of Energy June 1982) proposed modifying pre-existing facilities or constructing new facilities, as necessary, to solidify the HLW, treat the LIW, and subsequently place all wastes in temporary storage. The FEIS did not describe office and service facilities for workers. The FEIS (Section 1.6) did address various site operations that would be needed to support the primary mission of waste solidification, including operations necessary for ensuring compliance with environmental regulations (U.S. Department of Energy June 1982 ). However, the FEIs did not fully quantify the impacts or potential accident impacts to the environment associated with general site operations.

\section{Modified-Process Description}

Modification of facilities and construction of new facilities continue as necessary to support the WVDP mission. Treatment and placement of LIW in temporary storage is an ongoing activity, and vitrification operations were started in June 1996. General site operations include wastewater treatment, improvements to site infrastructure, waste minimization, and pollution prevention.

The WVDP has a sanitary and industrial wastewater treatment facility, which treats sewage and various nonradioactive wastewaters from physical plant systems le.g., water plant production residuals and boiler blowdown). Effluent from the treatment facility is discharged to site surface water through a New York state Pollutant Discharge Elimination system-permitted outfall (see Fig. 2-1). The wVDP ships digested sludge and untreated wastewater from the site sanitary and industrial wastewater treatment facility to the Buffalo sewer Authority for treatment.

As part of general site operations, routine maintenance and improvements/upgrades are made to elements of the site infrastructure. Major improvements include expanding parking capacity, replacing the cooling tower, upgrading the site underground petroleum fuel storage tanks, expanding the site utility room, replacing the LIwTE and decontamination, demolition, and disposal of the old LLwTF building in the near future.

The shipment of materials from the WVDP requires the use of a safe and effective transportation system. The site's rail system has been identified as the preferred means for transportation of HLW. The 1982 FEIS (Section B.5.1.1) assumed that HLW 
WVDP-321

Rev. 0

Page 23 of 67

would be transported exclusively by rail (U.S. Department of Energy June 1982). To allow for safe rail use at the site, the railroad spur requires repair and ongoing maintenance before and during transportation activities. The railroad spur was last inspected and repaired in 1989 in anticipation of its subsequent use; the spur was not used at that time and has not been repaired since.

Repair and maintenance of the railroad spur is addressed in section $B .5$ of the 1982 FEIS. The FEIS recognized that "the track servicing the West Valley site is a spur off the Chessie system (Baltimore and Pittsburgh). The poor condition of this spur warrants consideration prior to its use in this program." It is assumed that the spur would be put into serviceable condition and that it would be of similar quality to connecting rail lines. The nonradiological impacts of repair and maintenance of the site railroad spur were not defined specifically in the FEIs because they were (and continue to be) considered too trivial to be specifically described and analyzed.

The WVDP has implemented a long-term program to minimize the generation of all nonradioactive wastes, including hazardous waste, industrial waste, and sanitary waste. Goals for waste reduction in 1996, as compared to those established in a 1993 baseline waste generation study, included a $26 \%$ reduction of hazardous waste, an $18 \%$ reduction of industrial waste and a 108 reduction in sanitary waste. Each of these goals were greatly exceeded (West Valley Nuclear services Co., Inc. 1997). Specific programs that contributed to these reductions included recycling of paper, galvanized steel, carbon steel, stainless steel, aluminum, certain hazardous waste, and industrial waste.

\section{References}

U.S. Department of Energy. June 1982. Final Environmental Impact Statement: Long-Term Management of Liquid High-Level Radioactive Wastes Stored at the Western New York Nuclear Service Center, West valley. DOE/EIS-0081.

West Valley Nuclear Services Co., Inc. 1997. WVDP Annual Site Environmental Report for Calendar Year 1996. p. xlix.

\subsection{Eacility Decontamination}

\section{EEIS Process Description}

The FEIS (p. 2-3) assumed that the existing facility, with modifications, would be used for waste solidification (U.S. Department of Energy June 1982). In order to use the existing facilities, extensive decontamination was anticipated that would reduce 
WVDP-321

Rev. 0

Page 24 of 67

the radiation levels and allow personnel to enter and install the new process equipment while adhering to the philosophy of keeping personnel exposure as low as reasonably achievable (AIARA). The EEIs assumed that initial decontamination would be completed before HLW solidification began and recognized that further decontamination could be performed during waste processing.

"[I]t may be advantageous to remove the equipment from the other cells and perform some decontamination since this would advance the goal of final plant decommissioning, while allowing greater operational flexibility during

processing. Some of these cells could be decontaminated while the wastes were being solidified (p. B-53)."

Following solidification of HLW, the facilities used in the wvDp program would be decontaminated and decommissioned in what the 1982 FEIS called "final decontamination" in accordance with applicable requirements. The below-grade HLw storage tanks would be filled with cement and left in place.

\section{Modified-Process Description}

Initial decontamination of the entire plant was not completed before HLF solidification began, at which time $70 \%$ of the original facility had been partially decontaminated and reused for the WVDP. Due to funding shortfalls in 1988, the DOE descoped ongoing decontamination activities on the major cells in the process plant and used the available funds to run the HLW pretreatment system (U.S. Department of Energy January 5, 1988).

As indicated above, the 1982 FEIs had acknowledged that the initial decontamination could be conducted while the wastes were being solidified. Currently proposed activities at the WVDP include resuming the decontamination of Project facilities, as had been planned in the late 1980 s as well as decontamination and disposal of the LIFTF building.

Completion of the initial decontamination activities, as identified in the 1982 FEIS, will require removal of residual fuel-containing wastes and various other radioactive wastes located in the former process building. Materials will be removed, treated as necessary for safe storage and/or disposal (including volume-reduction and water or organic removal), characterized, packaged, and then placed in interim storage or moved off-site. The radiological impact analyses of decontamination activities in the process cells and plant presented in the 1982 FEIs also apply to the activities currently proposed for cells in the former process building. 
WVDP-321

Rev. 0

Page 25 of 67

After the remaining spent Nuclear Fuel (SNF) is shipped, the fuel receiving and storage area (FRS) and fuel pool would be placed in safe lay-up. From 1986 to 1987 , two-thirds of the FRs pool was prepared for safe lay-up by removing, decontaminating, and volume-reducing the unused SNF assembly canisters and racks. At that time, sludge and debris from the pool bottom were vacuumed and collected in an on-line high-integrity container (U.S. Department of Energy 1987). The vacuuming operations utilized filters to catch small particulates. These filters, as well as some nonfuel debris removed from the pool floor were placed into four modified fuel storage canisters which would also be dispositioned during FRs fuel pool decontamination. Similar decontamination activities would be conducted during current decontamination activities, and unused equipment and filters would be removed. scabbling of hotspots on the concrete may be required to remove residual contamination, and eventually the pool would be drained, painted, and re-filled with demineralized water.

Following vitrification of the high-level wastes, the facilities for removal, transfer, and processing of the HLW are to be deactivated in preparation for eventual decommissioning. The deactivation process will substantially remove all waste material from the facilities and prepare the facilities for custodial care until final decontamination. During this deactivation activity, equipment not needed for decommissioning or low-level waste processing could be removed, prepared for longterm custodial care or prepared for abandonment as appropriate.

Final decommissioning of the WVDP is the subject of the Draft Environmental Impact statement for Completion of the West Valley Demonstration Project and closure or Long-Term Management at the Western New York Nuclear service Center (U.S. Department of Energy 1996).

\section{References}

U.S. Department of Energy. June 1982. Final Environmental Impact Statement: Long-Term Management of Liquid High-Level Radioactive Wastes stored at the Western New York Nuclear Service Center, West Valley. DOE/EIS-0081.

- 1987. Spent Nuclear Fuel Removal Program at the west Valley

Demonstration Project. Topical Report DOE/NE/44139-37.

- January 5, 1988. FY88 Program Guidance Letter Number 2, w. W. Bixby to Mr. J. E. Krauss. Letter DW: 88:0004.

- 1996. Draft Environmental Impact statement for completion of the West Valley Demonstration Project and closure or Long-Term Management of Facilities at the Western New York Nuclear Service Center. DOE/EIS-0226-D. 
WVDP-321

Rev. 0

Page 26 of 67

\subsection{Spent Nuclear Fuel (SNF) Storage at the WVDP}

\section{FEIS Process Description}

Spent fuel has been stored at the site since before the beginning of the WVDP. When the DOE assumed control of the WVDP in 1982, 750 fuel assemblies were stored in the on-site fuel pool. This fuel was owned by NFS (125 assemblies) and four public utilities (625 assemblies). Anticipating that NFS and the utility owners would bear responsibility for the prompt (i.e., within two years) removal and transport of the spent fuel assemblies from the site, the impact analysis included in the FEIs was limited only to the short-term spent fuel removal. The FEIS made no attempt to quantify any potential long-term environmental impacts associated with extended spent fuel storage at the WVDP. Radiological risk estimates for all of the FEIS alternatives were presented in the cumulative impacts analysis (Section 4.4). The FEIS assumed that all 750 spent fuel assemblies would be transported a nominal distance of 1,000 miles $(1,600$ kilometers) to unspecified alternate SNF pool storage locations. The occupational dose estimated for these activities was 150 person-rem. The collective (population) dose estimate was 19 person-rem, primarily assigned to persons living along a hypothetical transportation route.

Modified-Process Description

Under a contract between NFS and the DOE, ownership of the 125 NFS spent fuel assemblies was transferred to the DOE at the WVDP. By October 1983 the commercial spent fuel owners had been ordered by the U.S. District Court (February 1982) to remove the fuel from the West Valley site, and the DOE began to develop plans to ship the NFS fuel to another DOE facility. Between 1983 and 1986, the utility-owned commercial spent fuel was removed from the west valley site during four separate campaigns that involved 257 accident-free shipments. By early 1985, only the 125 assemblies formerly owned by NFS lacked definitive plans for removal and relocation from the WVDP site.

The DOE had set June 30, 1986 as a target date for the removal of the remaining spent fuel from the West Valley storage pool. Delays in the NRC licensing process and funding shortfalls forced the postponement of this shipment. In November 1986, recognizing the impending delays, the DOE and the New York state Energy Research and Development Authority (NYSERDA) signed an agreement allowing continued storage of the remaining 125 fuel assemblies in the West Valley storage pool. This agreement permitted continued storage until the NRC issued Certificates of Compliance (COCs)

WVDP : 0006405.01 
WVDP-321

Rev. 0

Page 27 of 67

for the fuel removal casks. The DOE was to obtain cocs as quickly as practicable and pay all costs associated with continued storage. Notwithstanding regulatory approval of the casks by the NRC, actual shipment of the spent fuel to the Idaho National Engineering Laboratory (INEI) was further delayed after 1989.

In 1990, as a precondition to relocating the WVDP spent fuel to INEL, the DOE determined that an evaluation under NEPA would be necessary to support an action decision to transport the spent fuel from the WVDP to INEL's Test Area North. A draft Environmental Assessment had been completed and was under active review at the DOE in October 1991 when secretary of Energy James watkins, in a letter addressed to both of Idaho's U.S. Senators, retracted the program plan to relocate the wVDP spent fuel to INEL.

In an unrelated court proceeding in mid-1993 (U.S. District Court June 1993), the Federal District Court in Idaho ruled that the DOE must prepare an EIS to support future DOE-INEL decisions to (1) continue to receive spent fuel from the Fort st. Vrain reactor site in Colorado at the INEL Irradiated Fuels storage Facility, continue to receive and store SNF from various Department of the Navy and DOE operations, and (3) to accept and store the WVDP SNF at the Test Area North.

In April 1995, the DOE published the Programmatic spent Nuclear Fuel Management and INEL Enviromental Restoration and Waste Management Programs Final Environmental Impact statement (U.S. Department of Energy 1995). The record of decision (RoD), issued by DOE on June 1, 1995, stipulated that all DOE-owned non-aluminum clad SNF (including the 125 assemblies from WVD) would eventually be transferred to INEL for long-term storage. According to this agreement, the earliest date that wVDP SNF could be relocated to INEL is January 1, 2001.

The basic assumptions and conclusions contained in the 1982 FEIs and in various subsequent environmental and safety evaluations indicate that no significant environmental or health risks are anticipated with continued short-term on-site storage of spent fuel at the WVDP. Although significant delays in the original plans for removing all of the spent fuel assemblies have occurred, current plans call for the removal of the remaining 125 assemblies sometime after January 1, 2001 (but before the end of 2005) and relocation to the Idaho National Engineering and Environmental Laboratory (INEEL). (INEL was redesignated INEEL in 1996.) The potential radiological risks and other environmental impacts associated with the proposed removal from the WVDP, transportation to INEEL for another site designated by the DOE), and interim storage are fully evaluated in the Programmatic spent Nuclear Fuel Management and INEL Environmental Restoration and Waste Management Programs Final Environmental Impact statement (U.S. Department of Energy 1995 ). 
WVDP-321

Rev. 0

Page 28 of 67

Concurrence from the state of Idaho for this proposed transportation, receipt, and interim storage of fuel shipped from the WVDP is specifically included in the october 1995 settlement Agreement.

\section{References}

U.S. District Court. February 18, 1982. Settlement Agreement stipulation, and order. western District of New York. CIV-81-18E and CIV-81-683E.

U.S. Department of Energy. June 1982. Final Environmental Impact Statement: Long-Term Management of Liquid High-Level Radioactive Wastes stored at the Western New York Nuclear service Center, West Valley. DOE/EIS-0081.

U.S. District Court. June 28, 1993. Order Granting Motion for summary Judgment, Injunction, and Administratively Terminating Action. District of Idaho. Civil No. 910035-S-HLR and Civil No. 91-0054-S-HLR.

U.S. Department of Energy. 1995. Programmatic spent Fuel Nuclear Fuel Management and INEL Environmental Restoration and Waste Management programs Final Environmental Impact statement. DOE/EIS-0203-F. 
WVDP-321

Rev. 0

Page 29 of 67

CHAPTER 3.0

ENVIRONMENTAI IMPACTS OF WVDP PROCESSES AND MODIFICATIONS

As noted in Chapter 1 of this report, the 1982 FEIS (U.S. Department of Energy June 1982) was issued based on the best available information, before any commitment was made to proceed with detailed design efforts or other major vitrification-related activities. The 1982 FEIs was, of necessity, conceptual with respect to certain aspects of the WVDP, including projected releases and impacts on the public. Page ii (f) of the FEIS states: "The proposed action is intended to demonstrate the solidification of high-level waste for disposal. As a result, it is possible that design changes or other similar actions may occur." The 1982 FEIS's associated Record of Decision (ROD) recognized that "ongoing efforts will further refine design, construction, and operational aspects of the WVDP. The process of the actual wVDP, as built, may therefore differ from the present descriptions due to the incorporation of refinements from the development program. Such refinements are not expected to substantially alter the projected environmental impacts."

To address these anticipated design refinements, the 1982 FEIs committed the Project to detailed review of the potential impacts through detailed safety analyses of the operational systems.

"Consideration of the details of the operational systems involved in implementing the alternatives is beyond the scope of the EIs, which deals with conceptual designs only. After the choice of a specific alternative is made, the engineering and design of plant safety details. . will be covered in a safety Analysis Report (SAR)." (EEIS p. H-15, Response to H. 2.1.5).

Various activities in support of the WVDP are the present-day manifestation of what the ROD recognized as "refinements from the development program." Current examples of such activities include HLW tank heel removal, activities to support interim storage and ship-out of HLW, the construction and operation of the remote-handled waste facility, vitrification equipment disposition and dissolution, head end cell waste retrieval, ship-out of spent nuclear fuel to the INEEL and decontamination of the FRS pool, repair and maintenance of the railroad spur, decontamination/demolition and off-site disposal of the LLWTF and various other similar and related activities.

WVDP: 0006405.01 
WVDP-321

Rev. 0

Page 30 of 67

As processes have been defined for the WVDP, their associated environmental impacts have been assessed with safety analyses (in addition to other lower tier environmental documents) and re-reviewed as process refinements are required. Safety Analysis Reports (SARs) were thus committed to in the 1982 FEIS, and although not NEPA documents, per se, are valid analytical NEPA-support documents.

As the WVDP process has been better defined, release projections have been evaluated on a process-element specific basis within SARs, and actual releases have been measured and reported in the annual site environmental monitoring reports. Release impacts and estimated doses as a consequence of vitrification were not quantified on an annual basis in the FEIS. Instead, the FEIS projected releases on a processelement specific basis, with multi-year and potentially overlapping year impacts.

Quantitative comparisons of several environmental impacts from the FEIS and from more recent projections and actual measured values are provided in Tables 3-1 through 3-4. Categories for comparison include routine (or expected) radioactive releases, radiological risks due to routine operation, and collective (population) dose estimates from routine operations and occupational exposure. The incremental impacts of the process refinements are discussed in the following sections.

\section{References}

U.S. Department of Energy. June 1982. Final Environmental Impact Statement: Long-Term Management of Liquid High-Level Radioactive Wastes stored at the Western New York Nuclear Service Center, West Valley. DOE/EIS-0081.

\subsection{Routine Releases}

Radiological

Table 3-1 compares the routine radioactive atmospheric and liquid releases and solid wastes projected in the 1982 FEIS (column 1) with those projected by a series of sARs (column 2) and actual measured values from wVDP annual site Environmental Report (SER) data (column 3). Table 3-2 summarizes the results of operational environmental monitoring since the beginning of the WVDP. Both liquid and gaseous release monitoring data have demonstrated a general decline in wVD releases.

Caution should be used in attempting to compare FEIs projections to recent wVDP operational environmental monitoring data. The 1982 FEIs made no attempt to quantify the extent of radioactive contamination pre-existing in the environment and facilities. Because the DOE had not conducted a baseline assessment, the extent of pre-WVDP contamination was not fully accounted for before preparing the 1982 FEIS.

WVDP : 0006405.01 
WVDP-321

Rev. 0

Page 31 of 67

All 1982 FEIS release projections were based on the HLW source term and estimates of process releases during solidification. Therefore, the monitoring data are not directly comparable to incremental 1982 FEIS projections, since environmental monitoring data include radiological contributions attributable to pre-Project contamination. This effect can easily be seen in the footnote to the liquid release data in Table 3-2 in the years 1984 and 1985. Despite these limitations, the comparison of projected (1982) impacts and actual measured releases is valuable. Tables 3-1a and 3-1b indicate that atmospheric and liquid releases from initial decontamination were estimated in the FEIS at a total of $1.1 \times 10^{-3} \mathrm{Ci}$ and $1.1 \times 10^{-1}$ Ci, respectively. To estimate the amount actually released during the initial decontamination, the atmospheric and liquid discharge monitoring results as reported in the sER were examined for the years 1985-1987. This covers the period when decontamination was taking place. Compared to the annual releases prior to decontamination (1982-1984), as can be seen in Table 3-2, there was no noticeable increase in radioactive releases during the decontamination.

As presented in Table 3-ia, the total atmospheric release estimated in the FEIs for HLW solidification, including removal from tanks, decontamination of salt, calcination and vitrification, was approximately $4 \times 10^{-2} \mathrm{Ci}$. Annual Site Environmental Report data from 1988 to 1997 show atmospheric releases for the solidification process, which includes the STS, the LWTS, the css, and vitrification, was $1.0 \times 10^{-2} \mathrm{Ci}$. The total estimated liquid releases for HLW solidification were $3.8 \times 10^{-2} \mathrm{Ci}$; the actual releases reported in the Annual site Environmental Report from 1988-1997 were $4.1 \times 10^{-1} \mathrm{Ci}$.

The conditions for transport of Class A LLW remain essentially unchanged from that considered in the FEIS. Section B.5.1.2 of the 1982 FEIS identifies low-level waste forms, packaging requirements, transportation modes and routes, and radiological and non-radiological impacts to workers and the public under routine and accident conditions. Atmospheric and liquid releases from routine off-site transport continue to be negligible. Releases from on-site waste disposal and final decommissioning of Project facilities are being considered in the ongoing EIs for WVDP Completion and Site Closure (U.S. Department of Energy 1996).

The 1982 FEIS did not quantify impacts associated with on-going spent fuel storage at the WVDP because it was assumed all spent fuel would be removed early in the project. However, the FEIS did quantify impacts associated with fuel transportation from the WVDP. In light of the extended duration of spent fuel storage at the wVDP, DOE has prepared a Safety Analysis Report for the Fuel Receiving and storage Facility (FRs). 
WVDP-321

Rev. 0

Page 32 of 67

As seen in Tables 3-1a and 3-1b, the annual atmospheric and liquid releases estimated in association with the interim storage of spent fuel at the wVDP are $2.8 \mathrm{x} 10^{-5} \mathrm{Ci} / \mathrm{yr}^{-}$ airborne and $4.0 \times 10^{-4} \mathrm{Ci} / \mathrm{yr}$ liquid.

As seen in Table 3-1c, solid waste generated as a result of the wVDP was estimated to be nearly $140,000 \mathrm{ft}^{3}\left(4,000 \mathrm{~m}^{3}\right)$ in the 1982 FEIs (Table B.16).

More recent waste volume data are taken from DOE's Integrated Data Base Report (U.S. Department of Energy December 1997) and are reflected in column 4 of Table 3-1C. As stated above in section 2.3, Modified Process Description, additional Class A ILW production is currently estimated to be $18,000 \mathrm{ft}^{3}\left(500 \mathrm{~m}^{3}\right)$ per year, through the end of vitrification.

Mixed waste was not addressed in the 1982 FEIs since this category of waste was not legally defined until after 1982. Approximately $6,535 \mathrm{ft}^{3}\left(185 \mathrm{~m}^{3}\right)$ of mixed wastes are currently stored on-site (West valley Nuclear services Co., Inc. February 1998).

\section{Nonradiological}

Nonradiological impacts associated with WVDP activities were projected to be "small" or "insignificant" in the 1982 FEIS. The FEIs assumed (p. 4-41) that new facilities for ILW treatment, HLW, ILW, and TRU waste storage facilities, and some new laydown areas would occupy about 10 acres within the existing security fence. The area to be affected was next to existing facilities and was already cleared when the reprocessing facilities were built. Thus, construction impacts such as loss of habitat, preclusion of other land uses, and fugitive dust emissions would be insignificant (U.S. Department of Energy June 1982).

The FEIS (p. 4-42) projected that a risk of 53 osHA-recordable injuries and 0.8 deaths could occur during Project activities. However, this was based on a projected case rate of 15.86 injuries per million person hours for construction and decontamination and decommissioning and 2.1 injuries per million person hours for operations and disposal. These case rates are not based on current osha definitions of a "recordable injury" and are therefore not directly comparable. To date, 297 OSHA recordable injuries and no deaths have been reported at the wVD (West Valley Demonstration Project, OSHA 200 Logs).

Nonradioactive airborne releases were expected to be well below primary air standards. Similarly, liquid effluents were expected to meet all appropriate state 
WVDP-321

Rev. 0

Page 33 of 67

and federal standards. Because nonradioactive discharges were not quantitatively treated in the FEIs, comparison of the original and modified process is not possible. All point source releases from the WVDP, however, occur at permitted discharge points. Tables $3-3$ and 3-4 identify all atmospheric and liquid discharge points as well as their respective release limitations.

The total number of workers expected, at the height of operations, was approximately 500. Utility usage was expected to be about the same as when the fuel reprocessing plant was operating. Vitrification was expected to require about 10 acres of land, which had already been dedicated to nuclear use.

Due to funding limitations, operational constraints, and regulatory factors, HLw processing activities were extended beyond the period anticipated in the FEIS. The site population peaked at approximately 1,400 persons in 1995 as a result of vitrification construction activities. As a result of the increased site population and extended Project life, land and utility usage increased beyond that originally projected.

In October 1992, DOE issued an Environmental Assessment (U.S. Department of Energy October 1992) and FONSI for expansion of the wVDP sewage treatment plant to accommodate the larger site population. Similar smaller-scale site modifications are independently evaluated according to the DOE NEPA Regulations (10 CFR 1021 ) on an ongoing basis.

\section{References}

West Valley Demonstration Project. OSHA-200 Logs. 1982-1997.

U.S. Department of Energy. June 1982. Final Environmental Impact Statement: Long-Term Management of Liquid High-Level Radioactive Wastes Stored at the Western New York Nuclear Service Center, West Valley. DOE/EIS-0081.

U.S. Department of Energy. October 1992. Environmental Assessment for Proposed Wastewater Treatment Facility, West Valley Demonstration Project, New York. DOE/EA0622 .

- 1996. Draft Environmental Impact statement For Completion of the West Valley Demonstration Project and Closure or Long-Term Management at the Western New York Nuclear Service Center. DOE/EIS-0226-D.

- December 1997. Integrated Data Base Report - 1996: U.S. Spent Nuclear Fuel and Radioactive waste Inventories, Projections, and Characteristics. DOE/RW0006 , Rev. 13.

West Valley Nuclear Services Co., Inc. February 1998. Site Treatment Plan. WVDP-299 Rev. 0 . 
WVDP-321

Rev. 0

Page 34 of 67

\subsection{Doses Due to Routine Operations}

\section{occupational Exposure}

Table 3-5 compares the occupational dose predictions for the original and modified processes with actual measured doses. The total FEIs-projected occupational dose estimated for HLW solidification and LIW handling was 353 person-rem, plus 740 person-rem for initial decontamination. Actual occupational doses for HLW solidification measured from 1983-1997 totaled 162 person-rem plus 98 person-rem for initial decontamination (annual ALARA program summary dose reports). Occupational doses for all site activities listed in Table 3-5 totaled 424 person-rem for calender years $1983-1997$.

\section{off-site Dose}

Table 3-6 compares the 1982 FEIS estimated off-site radiological doses with sAR and SER estimated doses. The maximum individual dose from routine releases originally projected in the 1982 FEIS was $2 \times 10^{-4}$ rem. The current total estimated maximum offsite individual dose for all site activities, based on data reported in the sER, is $1.6 \times 10^{-3}$ rem. However, the current total estimated maximum off-site individual dose includes a contribution from groundwater (affected by former NFs operations), which was not included in the original FEIS.

Table 3-7 compares the annual collective population dose of the original estimates to actual site monitoring data from 1983-1997. The total cumulative dose commitment to the public since the start of operations totals 1.21 person-rem through 1997 , approximately $24 \%$ of the 5.1 person-rem dose estimated in the FEIs for the entire project. 
WVDP-321

Rev. 0

Page 35 of 67

CHAPTER 4.0

SUMMARY

This Supplement Analysis considers the potential environmental impacts associated with the continued operation of the West Valley Demonstration Project's high-level radioactive waste management process. The DOE does not propose any change in the quantity of high-level waste to be managed, the terminal waste form selected, or any other substantial change in the ongoing actions considered in the 1982 FEIs and subsequent NEPA documents.

Minor WVDP modifications and resulting environmental impacts are summarized below:

\section{SUMMARY OF PROCESS AND FACILITY MODIFICATIONS}

- Rather than being homogenized, supernate solutions and sludge from Tank 8D-2 will have been processed separately.

- Combined HIW sludge and ion-exchange media are being continuously fed to a melter for vitrification, thereby eliminating a spray calcinator and its attendant gaseous emissions.

- Process LLW has been solidified in cement rather than dried to a salt cake, resulting in an increased waste volume but a more stable final wasteform.

- LLW has been generated in quantities greater than originally anticipated and stored on-site rather than transported to a regional disposal facility, resulting in a substantial increase in on-site storage requirements.

- Currently there are no regional (<400 mi) LLW disposal facilities as assumed in the FEIS. LLW will be shipped greater distances for disposal.

- Site population, land and utility use, and duration of the WVDP have all exceeded 1982 FEIS assumptions.

- Interim storage of spent fuel continues at the WVDP. 
WVDP -321

Rev. 0

Page 36 of 67

SUMMARY OF ROUTINE RELEASES AND RISKS

- Atmospheric releases through 1997 associated with HLW solidification activities were 258 of the releases assumed in the FEIS (Table 3-1a). Atmospheric releases through the completion of vitrification should remain within original 1982 FEIS estimates.

- Total occupational dose associated with HLW solidification activities are within, and expected to remain within, the original estimates (Table 3-5).

- Collective population dose projections (Table 3-7) associated with HLW solidification activities are less than $25 \%$ of the original estimates. Collective population dose through the completion of vitrification should remain within original 1982 FEIS estimates.

- Total liquid releases from the site through 1997 (Table 3-1b) were slightly more than assumed in the FEIs for the HLW solidification activities. However, these releases include substantial contributions from former NEs operations.

- The off-site maximum individual dose projected in the 1982 FEIS (Table 3-6) is slightly exceeded by current estimated maximum off-site dose. However, these dose estimates include contributions from actual releases not associated with the HLW solidification activities.

Although slight increases have been discussed in some areas throughout the supplement Analysis, the overall impacts associated with these slight increases are within the range of uncertainty originally projected in the 1982 FEIS. 


\section{Process}

HLW Solidification

\section{Original WVDP Process}

The acidic THOREX waste would be removed from Tank $8 \mathrm{D}-4$ and directly processed into a terminal HLW form.

The neutralized PUREX waste in Tank 8D-2 would be homogenized, i.e., the sludge in the bottom of the tank would be mixed with the overlying supernatant liquid. The wastes would be pumped in batches to a holding tank and then to the main process building.

The sludge would be "washed" by mixing with the supernate and then separated out again by centrifugation or by settling and filtration.

The supernate would be passed through ion-exchange columns to be stripped of cesium, strontium, and actinides.

The sludge and contaminated ionexchange media would be mixed together, atomized in a spray calcinator, and the resultant calcine would be mixed with glass frit, melted, and poured in 300 stainless steel canisters $(2$ feet in diameter by 10 feet tall).

\section{Modified WVDP Process}

The acidic THOREX waste was mixed with the neutralized PUREX waste in $8 D-2$ prior to vitrification rather than being processed separately.

The PUREX waste in Tank 8D-2 was not homogenized. The supernate was decanted from the sludge and processed through IRTS.

The sludge was "washed" by mixing caustic (NaOH) and additional clean process water and separated out again by settling.

The supernate was processed through ionexchange columns for removal of cesium and strontium. The sludge wash water was also sent through ion-exchange columns to be treated for removal of strontium, cesium, and plutonium.

A mixture of tank 8D-2 sludge, acidic THOREX wastes, ion-exchange media (zeolite), and glass formers are being continuously fed to the ceramic melter to make approximately 300 stainless steel canisters (two feet in diameter by 10 feet tall). There is no spray calcinator step. 


\section{Process}

Management and Interim storage of Wastes

\section{Original WVDP Process}

The empty HLW tanks would be decontaminated with acids, filled with cement, and left onsite permanently.

HLW canisters would be stored on-site in a new HLW storage facility or use existing cells within the main plant. The canisters would eventually be transported in about 40 shipments in special railcar casks to a federal repository, when it became available for permanent disposal.

Following ion-exchange, the remaining liquid (non-HLW) wastes would be evaporated down to a LLW salt cake containing $2 \mu \mathrm{Ci} / \mathrm{g}$ of fission products and $0.4 \mu \mathrm{Ci} / \mathrm{g}$ of actinides. The evaporate would be released to the environment.

\section{Modified WVDP Process}

HLW tanks will be emptied to the greatest extent possible with the in-tank transfer pumps. The residual HLW within the tanks (HLW tank heels) will be removed to the greatest extent possible using mechanical and chemical means. Final closure of the empty HLW tanks will be determined upon issuance of the site Closure EIS Record of Decision.

HLW canisters are currently stored in High-Level Waste Interim Storage (HLWIS) at the WVDP (formerly the Chemical Process Cell). The DOE is considering continued storage in HLWIS, interim HLW storage at a site other than the WVDP (until the federal repository becomes available), or interim storage at a new facility at the WVDP. Ultimate disposal of the canisters at a federal repository remains DOE's responsibility under the WVDP Act.

Following ion-exchange, the remaining liquid wastes were evaporated, then cement-solidified producing a larger volume, but more stable waste form.

The evaporate was not released directly to the environment, but was condensed and treated through the LLWTF before being recycled or released to the environment. All liquid wastes from the lagoon system are discharged under DOE radionuclide-release criteria and a SPDES permit. 
Management and Interim storage of Wastes (continued)
Miscellaneous $L L W$ and TRU wastes would be generated during decontamination before solidification, and final D\&D of Project facilities following solidification. These wastes would be temporarily stored on-site in new storage facilities until a disposal site became available.

Hazardous and mixed waste (waste contaminated with both radioactive and hazardous waste constituents) impacts not addressed in the FEIS.

The LLW would be transported via trucks in about 1,700 shipments to a regional burial ground for permanent disposal. These wastes would mostly be contained in ordinary 55-gallon steel drums and steel boxes. The EIS assumed that the regional burial ground would be available in 1990 and would be located 400 miles from West valley.

The HLW canisters would be transported in about 40 shipments in special railcar casks to a federal repository when it became available for permanent disposal.
Larger than anticipated volumes of LLW are stored on-site due to the 1987 stipulation of Compromise. Various waste management facilities have been constructed (e.g., Lag storage Buildings) and will be constructed (e.g.., Remote Handled Waste facility) to support on-going waste management needs.

Miscellaneous hazardous wastes generated during Project operations are temporarily stored and subsequently disposed at licensed facilities in accordance with New York state and federal regulations.

Miscellaneous mixed radioactive wastes (MW) (characterized as class A) generated during Project operations are shipped, treated, and disposed of in accordance with the WVDP's site Treatment Plan. Those MW characterized as Class $B / C$ or TRU MW are stored on-site in the lag storage facilities pending the WVDP Completion and site Closure EIS ROD.

There are no regional disposal facilities within 400 miles as the FEIS assumed that are available for use. Waste must be shipped greater distances to a disposal facility. Consistent with the 1987 stipulation of Compromise, Class A LLW generated at the WVDP is shipped off-site for treatment and/or disposal. Class $B / C$ LLW remains in storage pending the WVDP Completion and site Closure EIS ROD.

HLW canisters are currently stored on-site pending DOE programmatic HLW management decisions. 
Process

Disposal/

Transport of

Wastes

(continued)

General site

Operations

Facility

Decontamination

Spent Fuel

Management

\section{Original WVDP Process}

Additional shipments of TRU waste, by truck, would be made to a federal repository.

Site operations were expected to span approximately 20 years, with a site population of 500 , use 10 additional acres of land, and use utilities equivalent to previous reprocessing operations.

Existing facilities would be modified or new facilities constructed for HLW solidification, LLW treatment, and subsequent waste storage. Basic infrastructure would be maintained to support the Project.

Decontamination would take place in two phases, initial (before and during waste solidification) and final

(decontamination of the entire facility for closure).

750 fuel assemblies were stored in the FRS with early shipout anticipated, and storage impacts were not addressed in the 1982 FEIS. Radiological and nonradiological transportation impacts were quantified in the 1982 FEIS.

\section{Modified WVDP Process}

TRU waste is currently stored on-site pending decisions regarding disposal of TRU wastes that will be made based upon the WVDP Completion and site closure EIS ROD.

Site operations will extend beyond 20 years with a site population that exceeded 1,400 at the peak of construction: There was also increased land and utility usage.

Existing facilities were modified. New facilities have been and continue to be constructed as needed to support HLW solidification, LLW treatment, and subsequent waste storage. Infrastructure and basic support system maintenance le.g., railroad spur maintenance, demolition and disposal of the LLWTF building) continues as necessary.

Initial decontamination will be on-going during the HLW solidification (e.g., head end cells and spent nuclear fuel storage pool decontamination). Final decontamination will be accomplished after the WVDP Completion and site closure ROD.

(1983-1986) 625 fuel assemblies shipped.

125 assemblies await removal and transportation to Idaho National Engineering and Environmental Laboratory after 2001 . 
TABLE 3-1: Comparison of Original and Modified WVDR Routine Radioactive Impacts A. ATMOSPHERIC

\begin{tabular}{|c|c|c|c|}
\hline EVENT & $\underset{(\mathrm{C} i)}{\operatorname{FEIS}}$ & $\begin{array}{c}\text { SAR (projected) } \\
\text { (Ci) }\end{array}$ & $\begin{array}{c}\text { Site Environmental Report } \\
\text { (SER) (Ci) }\end{array}$ \\
\hline $\begin{array}{l}\text { HLW SOLIDIFICATION } \\
\text { Removal from Tanks/STS } \\
\text { (Sludge wash) } \\
\text { Decontamination (salt) } \\
\text { Calcination } \\
\text { Vitrification } \\
\text { LWTS }\end{array}$ & 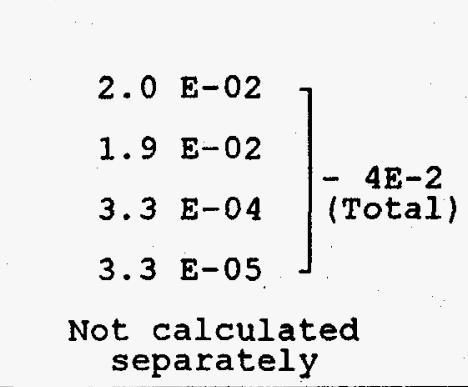 & $\begin{array}{l}1.5 \mathrm{E}-01 \text { (2) (Total) } \\
2.9 \mathrm{E}-05 \text { (3) (Total) } \\
\mathrm{N} / \mathrm{A} \\
3.6 \mathrm{E}-03 \text { (4) (Total) } \\
4.8 \mathrm{E}-01 \text { (5) (Total) }\end{array}$ & $\left.\begin{array}{ll}1.53 \mathrm{E}-5 & (10) \\
3.05 \mathrm{E}-6 & (11) \\
\mathrm{N} / \mathrm{A} \\
9.99 \mathrm{E}-3 \quad \text { (8) } \\
\text { not calculated } \\
\text { separately }\end{array}\right]-\frac{1.0 \mathrm{E}-2}{(\text { Total) }}$ \\
\hline $\begin{array}{l}\text { INTERIM STORAGE } \\
\text { HLW (post-solidification) } \\
\text { LLW } \\
\text { Spent Fuel }\end{array}$ & $\begin{array}{l}6.8 \text { E-02 } \\
\text { Assumed no releases } \\
\text { Not calculated }\end{array}$ & $\begin{array}{l}\text { Assumed no releases } \\
\text { Assumed no releases } \\
2.8 \text { E-05 (9) }\end{array}$ & $N / A \begin{array}{l}N / A \\
(\text { Sealed }) \\
(8)\end{array}$ \\
\hline DISPOSAL & Not calculated & (6) & $N / A$ \\
\hline TRANSPORTATION & Assumed no release & $\begin{array}{l}\text { Class A LLW - Assumed no } \\
\text { release } \\
\qquad \text { All other (6) }\end{array}$ & $N / A$ \\
\hline $\begin{array}{l}\text { DECONTAMINATION } \\
\text { Initial } \\
\text { Final }\end{array}$ & $\begin{array}{lll}1.1 & E-03 & (7) \\
3.4 & E-02 & (7)\end{array}$ & Not calculated separately & Not calculated separately \\
\hline
\end{tabular}

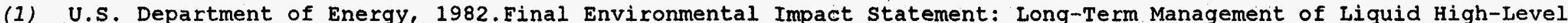
Radioactive Wastes stored at the Western New York Nuclear Service Center, West Valley. DoE/EIS-0081. Table 4.3. Unless noted otherwise, releases are calculated from release fraction, times the estimated 1987 radioactive inventory of wastes, Tables B.2 and B.4, times a 3-year release period.

(2) SAR-004, Rev. 7. Supernate Treatment System (STS) SAR.

(3) SAR-008, Rev. 1. Cement Solidification system (CSS) SAR, Table G.8.6-2.

(4) SAR-003, Rev. 1. Vitrification system (VS) PSAR, Section C.8.6.3.

(5) SAR-005, ReV. 3. Liquid Waste Treatment System (LWTS) SAR, Table H.8.6-2.

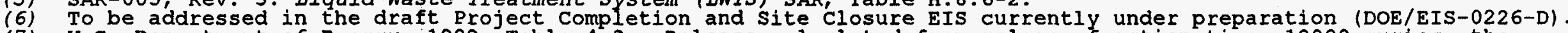

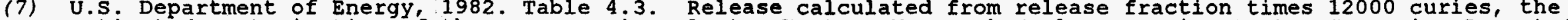
estimated contamination of the reprocessing plant. Western New York Nuclear service Center Companion Report for 1982 FEIS. TID-28905-2, P. 3-10.

(8) Releases directed through Main stack 1988-1997.

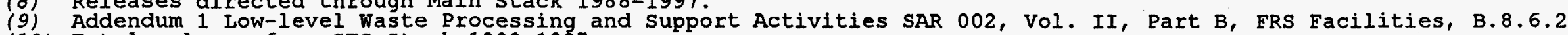

(10) Total release from STS Stack 1988-1997.

(11) Total release from CSS Stack 1988-1997.

$N / A$ - Not Applicable

WVDP : 0006405.01 
TABLE 3-1: Comparison of Original and Modified WVDP Routine Radioactive Impacts (continued) B. LIQUID

\begin{tabular}{|c|c|c|c|}
\hline EVENT & $\begin{array}{l}\text { FEIS } \\
(\mathrm{C} i)^{(1)}\end{array}$ & $\begin{array}{c}\text { SAR (projected) } \\
\text { (Ci) }\end{array}$ & $\begin{array}{c}\text { site Environmental Reports (SER) } \\
\text { (Ci) }\end{array}$ \\
\hline $\begin{array}{l}\text { HLW SOLIDIFICATION } \\
\text { Removal from Tanks/STS } \\
\text { (Sludge wash) } \\
\text { Decontamination (Salt) } \\
\text { Calcination } \\
\text { Vitrification } \\
\text { LWTS }\end{array}$ & $\begin{array}{l}\text { Assumed no release } \\
\left.\begin{array}{ll}3.0 & E-04 \\
3.3 & E-02 \\
3.3 & E-03 \\
9.3 & E-04\end{array}\right]-\begin{array}{l}3.8 E-2 \\
\text { (Total) }\end{array}\end{array}$ & $\begin{array}{l}9.8 \mathrm{E}+01(2) \text { (Total) } \\
\text { Liquid radioactive waste } \\
\text { from WVD is directed to } \\
\text { LLWT for treatment prior } \\
\text { to release }\end{array}$ & $\begin{array}{l}\text { 4.1E-1 (6) (Total) } \\
\text { Liquid radioactive waste from } \\
\text { WvDp is directed to LLWTE for } \\
\text { treatment prior to release }\end{array}$ \\
\hline $\begin{array}{c}\text { INTERIM STORAGE } \\
\text { HLW (post-solidification) } \\
\text { LLW } \\
\text { spent Fuel }\end{array}$ & $\begin{array}{l}\text { Assumed no release } \\
\text { Assumed no release } \\
\text { Not calculated }\end{array}$ & $\begin{array}{l}\text { (4) } \\
\text { Assumed no release } \\
4.0 \mathrm{E}-04 \text { (5) (Annual) }\end{array}$ & $N / A$ \\
\hline DISPOSAL & Not calculated & (4) & $N / A$ \\
\hline TRANS PORTATION & Assumed no release & $\begin{array}{c}\text { Class A LLW - Assumed no } \\
\text { release } \\
\text { All other (4) }\end{array}$ & $N / A$ \\
\hline $\begin{array}{l}\text { DECONTAMINATION } \\
\text { Initial } \\
\text { Final }\end{array}$ & $\begin{array}{l}1.1 \text { E-01 }(3) \\
3.4 \text { E-00 (3) } \\
(2 \text { year campaign) }\end{array}$ & $\begin{array}{c}\text { Not calculated } \\
(4)\end{array}$ & $N / A$ \\
\hline
\end{tabular}

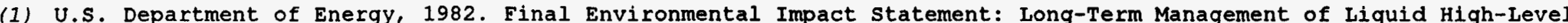
Radioactive Wastes stored at the Western New York Nuclear Service Center, West Valley. DOE/EIS-0081. Table 4.3. Unless noted otherwise, releases are calculated from release fraction times, the estimated 1987 radioactive inventory of wastes, Tables B.2 and B.4, times a 3 year release period.

(2) SAR-005, Rev. 3. Liquid Waste Treatment System (LWTS) SAR. 4.8.6.4 Projected Doses from Liquid Releases.

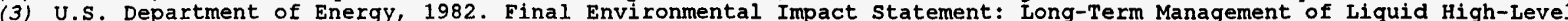
Radioactive Wastes stored at the Western New York Nuclear Service Center. West Valley. DoE/EIS-0081. Table 4.3. Release calculated from release fraction times 12,000 curies, the estimated contamination of the reprocessing plant. Western New York Nuclear Service Center Companion Report for 1982 EEIS. TID-28905-2 p. 3-10 Table 3.3.

(4) To be addressed in the Project Completion and site closure EIS currently under preparation (DOE/EIS-0226-D).

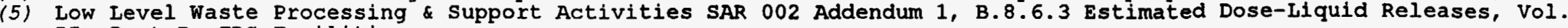
II, Part B, FRS Facilities.

(6) Calculated from 1988-1997 SER lagoon 3 discharge data.

N/A - Not Applicable 
TABLE 3-1: Comparison of Original and Modified WVDP Routine Radioactive Impacts (concluded) C. SOLID WASTE

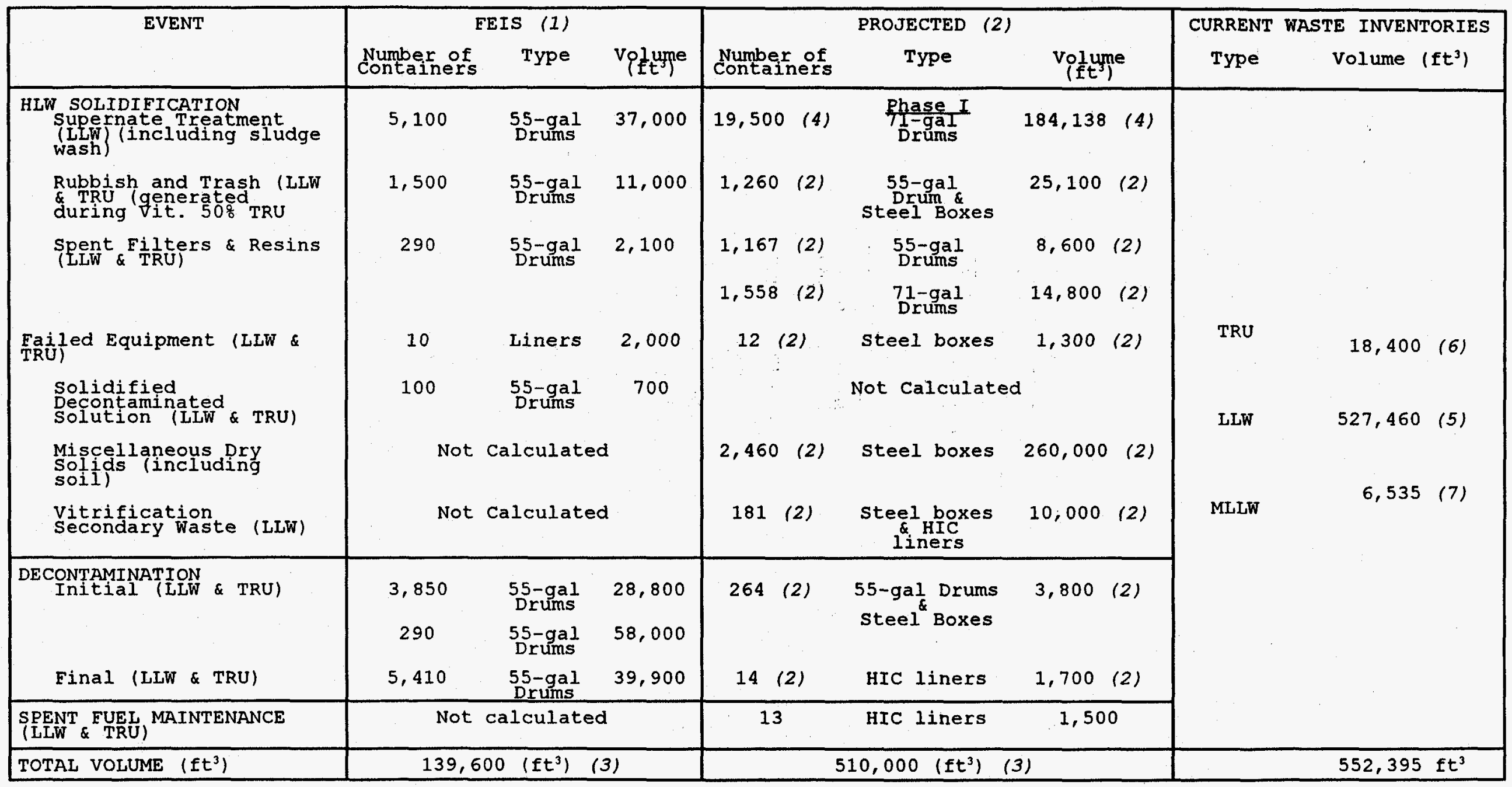

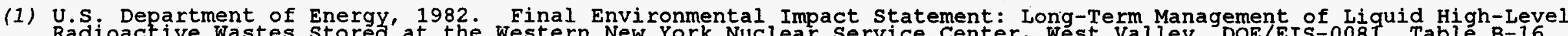

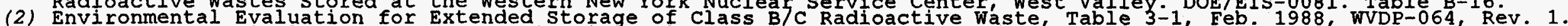

(3) Total does not include final decontamination volumes which will be addressed in the EIS' under preparation

(5) Current projection identified in Annual Waste Management Plan.

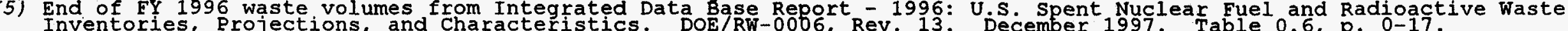

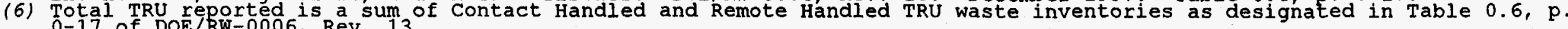

(7) WVDP-299, Site Treatment Plan, Rev. 0, FY97 Update. February 1998. p. 3.

WVDP: 0006405.01 


$$
\begin{aligned}
& 5 \\
& \text { No }
\end{aligned}
$$

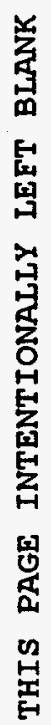




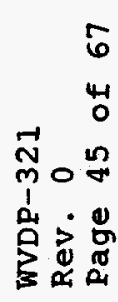

(⿻

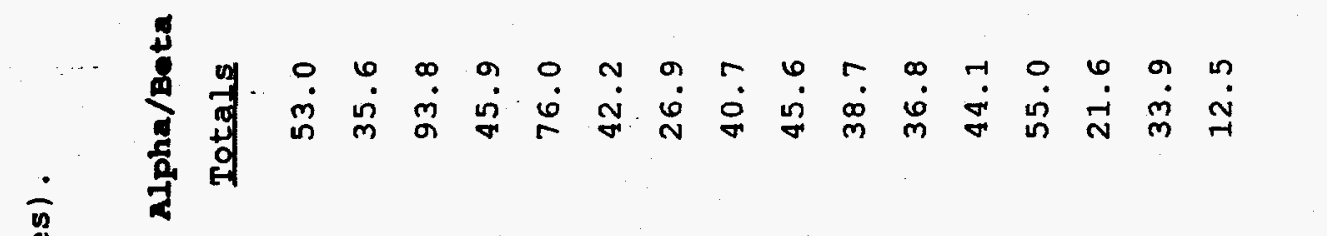

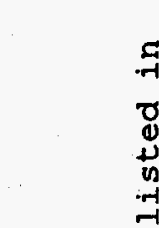

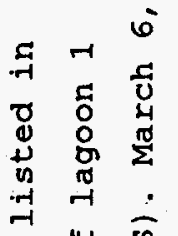

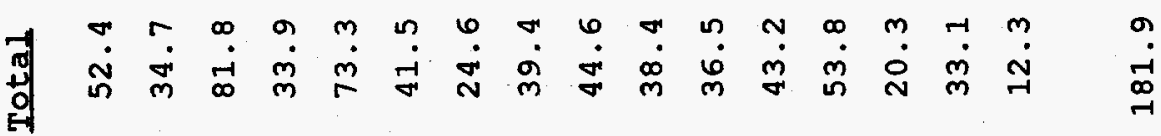

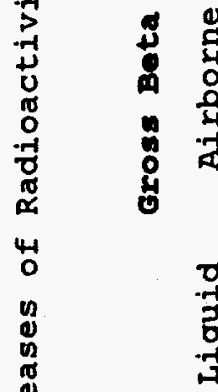

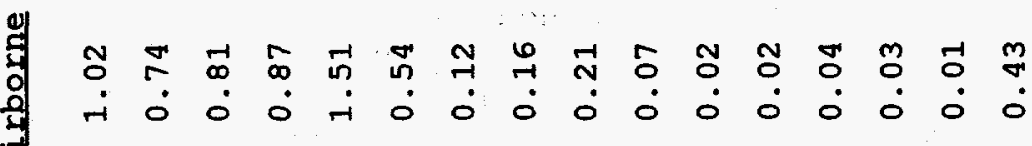

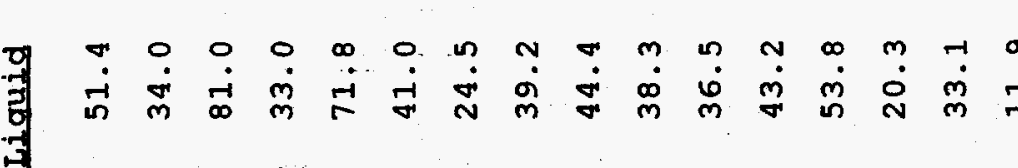

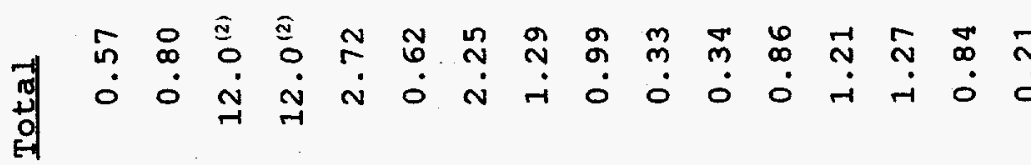

0
à

量

号.

㟧

क

0.7

ט.

고ำำ

ถ

मे

तิ

-

ข

טE⿱ 口甘

a

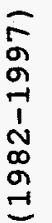

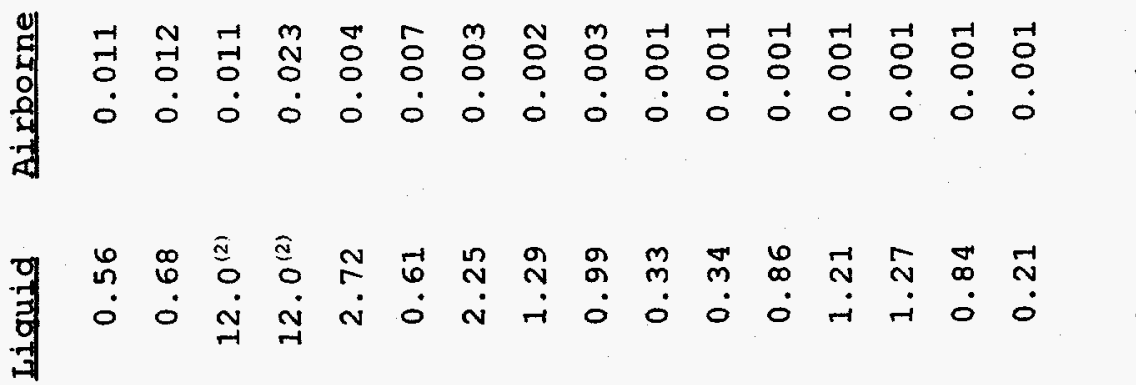

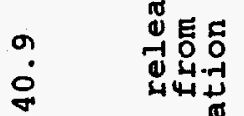

बन्न द्व

年买员

武整

U.

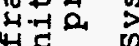

मी

๒ึ.

$\overbrace{0-1}^{\pi} \underset{7}{0}$

o

45 n.

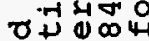

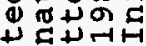

0 मे.

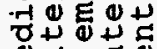

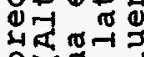

Q

दिनना

이ㄴㅚㅚ $N$.

$\ddot{N}$

목

D赵

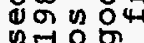

nी

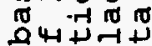

年

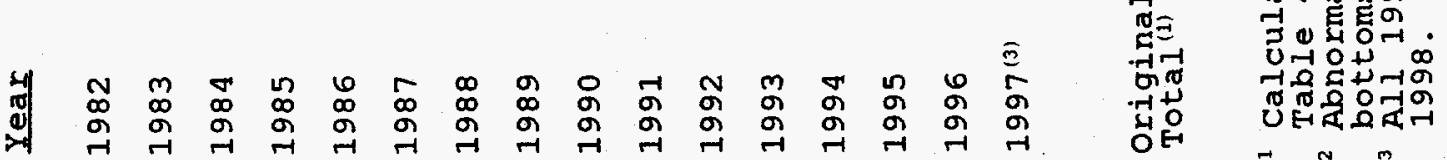


WVDP-321

Rev. 0

Page 46 of 67

THIS PAGE INTENTIONALIY LEFT BLANK

WVDP : 0006405.01 
WVDP-321

Rev. 0

Page 47 of 67

TABLE 3-3

WVDP ATMOSPHERIC REGUIATORY IIMITS*

Emission Pt./Description

1a) Process Building stack

1b) Process Building Chemical Emissions

2) Contact size-Reduction (CSR)

Low-Level Waste Compactor

4) Cement Solidification system (CSS) (01-14 bldg. ventilation)
Parameters

Alpha

Beta

$\mathrm{H}-3$

Co- 60

Sr -90

$I-129$

Cs -134

Cs -137

Eu-154

$\mathrm{U}-232$

$\mathrm{U}-234$

$\mathrm{U}-235$

$\mathrm{U}-238$

$\mathrm{Pu}-238$

$\mathrm{Pu}-239$

Am-241

Exempt per 6NYCRR Part 2013.2 (40)

\section{Iimit/Discharge Per Yr.}

1. $18 \mathrm{E}-06$

$4.34 \mathrm{E}-04$

1. $40 \mathrm{E}-01$

$6.87 E-08$

4. $50 \mathrm{E}-05$

$7.43 E-03$

1. 36E-07

3. $17 \mathrm{E}-04$

2. $33 E-07$

3. $58 \mathrm{E}-08$

4. $30 \mathrm{E}-08$

3. $38 \mathrm{E}-08$

3. $53 \mathrm{E}-08$

1. $82 \mathrm{E}-07$

$1.86 \mathrm{E}-07$

$7.31 \mathrm{E}-07$

$$
\begin{aligned}
& 1.56 E-09 \\
& 1.51 E-08 \\
& 4.31 E-09 \\
& 3.48 E-09 \\
& 8.07 E-09 \\
& 3.86 E-09 \\
& 5.43 E-09 \\
& 6.31 E-09 \\
& 3.43 E-09 \\
& 1.14 E-09 \\
& 2.48 E-10 \\
& 4.56 E-10 \\
& 3.87 E-10 \\
& 1.38 E-10 \\
& 3.17 E-10
\end{aligned}
$$

Not operating

$$
\begin{aligned}
& \text { Alpha } \\
& \text { Beta } \\
& \text { Co-60 } \\
& \text { Sr-90 } \\
& \mathrm{I}-129 \\
& \mathrm{Cs}-134 \\
& \mathrm{Cs}-137 \\
& \mathrm{Eu}-154 \\
& \mathrm{U}-232 \\
& \mathrm{U}-234 \\
& \mathrm{U}-235 \\
& \mathrm{U}-238 \\
& \mathrm{Pu}-238 \\
& \mathrm{Pu}-239 \\
& \mathrm{Am}-241
\end{aligned}
$$

$9.80 \mathrm{E}-09$

$2.91 E-08$

1. $16 \mathrm{E}-08$

1. $77 \mathrm{E}-08$

4. $82 \mathrm{E}-07$

1. $21 \mathrm{E}-08$

1. $28 \mathrm{E}-0 \mathrm{~B}$

3. $48 \mathrm{E}-08$

8. $69 \mathrm{E}-09$

6. 64E-09

6. $89 \mathrm{E}-10$

5. 85E-09

8. $96 \mathrm{E}-10$

4. $36 \mathrm{E}-10$

1. $06 \mathrm{E}-09$

ci/yr

Values given in limit/discharge per year column are maximum values permitted. Where no discharge limits are specified, actual 1997 discharge data has been provided. 
TABLE $3-3$

WVDP ATMOSPHERIC REGUIATORY LIMITS (continuEd) *

\section{Emission Pt./Description}

5) Supernatant Treatment system (STS) Ventilation/off-gas

$6,7)$ Boilers (x 2)

$$
\mathrm{SO}_{2}
$$$$
\mathrm{NO}_{\mathrm{x}}
$$

8) Nitric Acid Tank (a.k.a. 33013)

9) css cement silo

10) LLW Treatment Hot

11) LLW Treatment cold

12) Laundry Vent

\section{Parameters}

$$
\begin{aligned}
& \text { Alpha } \\
& \text { Beta } \\
& \text { H-3 } \\
& \text { Co-60 } \\
& \text { sr-90 } \\
& \mathrm{I}-129 \\
& \mathrm{Cs}-134 \\
& \mathrm{Cs}-137 \\
& \mathrm{Eu}-154 \\
& \mathrm{U}-232 \\
& \mathrm{U}-234 \\
& \mathrm{U}-235 \\
& \mathrm{U}-238 \\
& \mathrm{Pu}-238 \\
& \mathrm{Pu}-239 \\
& \mathrm{Am}-241
\end{aligned}
$$
Total Particulates

Exempt per 6NYCRR Part 2013.3 (33)

Exempt per 6NYCRR Part 2013.2 (27)

Permit is not necessary. Periodic confirmatory sampling is conducted for annual reporting purposes.

$$
\begin{aligned}
& 5.08 E-09 \\
& 4.72 E-07 \\
& 3.30 E-05 \\
& 6.98 E-09 \\
& 4.82 E-08 \\
& 1.09 E-06 \\
& 6.88 E-09 \\
& 3.14 E-07 \\
& 1.75 E-08 \\
& 4.30 E-09 \\
& 4.55 E-09 \\
& 4.36 E-10 \\
& 3.46 E-09 \\
& 5.57 E-10 \\
& 2.10 E-10 \\
& 5.80 E-10
\end{aligned}
$$

$\mathrm{ci} / \mathrm{yr}$

$5241 \mathrm{bs} / \mathrm{y}$ (each)

\section{Limit/Discharge Per Yr.}


WVDP-321

Rev. 0

Page 49 of

TABLE 3-3

WVDP ATMOSPHERIC REGULATORY IIMITS (continued) *

Emission Rt./Description

13) CCF-Solids Transfer system (CTS-02 - Cold Chem)

\section{Parameters}

Aluminum Hydroxide

Aluminum Nitrate

Aluminum oxide

Barium Hydroxide octahydrate

Barium Nitrate

Barium oxide

Calcium Carbonate

Calcium Nitrate

Calcium oxide

Cerium Hydroxide

Cerium Nitrate

Cerium oxide

Chromium oxide Hydrate

Chromium Oxide

Cesium Hydroxide Monohydrate

Cesium Nitrate

Cesium oxide

Copper Hydroxide

Copper Nitrate

Copper oxide

Iron Oxide

Ferrous Nitrate

Potassium Hydroxide

Potassium Formate

Potassium Nitrate

Potassium oxide

Lanthanum oxide

Lithium Hydroxide Monohydrate

Lithium Formate

Lithium Nitrate

Lithium oxide

Magnesium Hydroxide

Magnesium Nitrate

Magnesium Oxide

Manganese Oxide

Manganese Dioxide

Sodium Molybdate

Sodium Formate

Neodymium Oxide

Nickel Hydroxide

Nickel Nitrate

Nickel oxide

Sodium Phosphate Monobasic

Sodium sulfate

Silicon oxide

Strontium Hydroxide

Strontium Nitrate

strontium oxide

Titanium oxide

Zinc oxide

Zirconium oxide

Zirconium Hydroxide

Sodium Chloride

Sodium Fluoride

Rhodium Oxide

Ruthenium oxide

Palladium oxide

Sucrose

Sodium oxalate

Sodium Tetraborate Decahydrate

Boric oxide

Sodium Monoxide

Sodium Nitrate

Sodium Nitrite

Zeolite

Total Solid particulates

Boric Acid
Limit/Discharge Per Ir.

8. 06E-2

$1.92 \mathrm{E}-1$

$7.65 \mathrm{E}-2$

$1.55 \mathrm{E}-2$

$1.28 \mathrm{E}-2$

$7.70 \mathrm{E}-3$

$2.44 \mathrm{E}-2$

$4.0 \mathrm{EE}-2$

1. $53 \mathrm{E}-2$

$9.30 \mathrm{E}-3$

1. $73 \mathrm{E}-2$

$7.70 \mathrm{E}-3$

$4.50 \mathrm{E}-3$

$3.80 \mathrm{E}-3$

$4.60 E-3$

$5.30 \mathrm{E}-3$

$3.80 \mathrm{E}-3$

$1.90 \mathrm{E}-3$

3. $60 \mathrm{E}-3$

$1.50 \mathrm{E}-3$

1. $53 \mathrm{E}-1$

3. $91 \mathrm{E}-1$

$6.22 \mathrm{E}-2$

$9.58 \mathrm{E}-2$

1. $12 \mathrm{E}-1$

$5.36 \mathrm{E}-2$

$8.00 \mathrm{E}-4$

$1.50 \mathrm{E}-1$

1. $39 \mathrm{E}-1$

$2.46 \mathrm{E}-1$

$5.36 \mathrm{E}-2$

$2.06 \mathrm{E}-2$

$5.23 \mathrm{E}-2$

$1.53 \mathrm{E}-2$

$1.88 \mathrm{E}-2$

$3.90 \mathrm{E}-3$

$2.00 \mathrm{E}-4$

3. $68 \mathrm{E}-1$

$2.30 \mathrm{E}-3$

$7.10 \mathrm{E}-3$

1. $25 \mathrm{E}-2$

$5.70 \mathrm{E}-3$

$6.47 \mathrm{E}-2$

2. $72 \mathrm{E}-2$

$2.90 \mathrm{E}-1$

$9.00 \mathrm{E}-3$

$1.56 \mathrm{E}-2$

$7.70 \mathrm{E}-3$

$1.53 \mathrm{E}-2$

$7.70 \mathrm{E}-3$

3. $84 \mathrm{E}-2$

$4.95 \mathrm{E}-2$

$2.30 \mathrm{E}-3$

$2.30 \mathrm{E}-3$

$2.30 \mathrm{E}-3$

$2.30 \mathrm{E}-3$

$2.30 \mathrm{E}-3$

$1.54 \mathrm{E}-1$

3. $63 \mathrm{E}-1$

$3.14 \mathrm{E}-1$

1. $14 \mathrm{E}-1$

$1.03 \mathrm{E}-1$

$2.85 \mathrm{E}-1$

$2.31 \mathrm{E}-1$

1. $37 \mathrm{E}-1$

4. $66 \mathrm{E}-2$

2.03E-1 
TABLE 3-3

WVDP ATMOSPHERIC REGUIATORY IIMITS (continued) *

Emission Pt./Description

14) CCF-Vessel

Ventilation system (CTS-03 - Cold Chem)
Parameters

Iimit/Discharge Per Yr.
Aluminum Hydroxide

Aluminum Nitrate

Aluminum oxide

Barium Hydroxide Octahydrate

Barium Nitrate

Barium oxide

Calcium Carbonate

Calcium Nitrate

Calcium oxide

Cerium Hydroxide

Cerium Nitrate

Cerium oxide

Chromium oxide Hydrate

Chromium Oxide

Cesium Hydroxide Monohydrate

Cesium Nitrate

Cesium oxide

Copper Hydroxide

Copper Nitrate

Copper Oxide

Ferric Hydroxide

Iron oxide

Ferrous Nitrate

Potassium Hydroxide

Potassium Formate

Potassium Nitrate

Potassium Oxide

Ianthanum oxide

Lithium Hydroxide Monohydrate

Iithium Formate

Lithium Nitrate

Lithium oxide

Magnesium Hydroxide

Magnesium Nitrate

Magnesium Oxide

Manganese Oxide

Manganese Dioxide

Sodium Molybdate

Sodium Hydroxide

Sodium Formate

Neodymium Oxide

Nickel Hydroxide

Nickel Nitrate

Nickel oxide

Sodium Phosphate Monobasic

Phosphoric Acid

sodium sulfate

Silicon Oxide

Strontium Hydroxide

strontium Nitrate

strontium oxide

Titanium oxide

Zinc oxide

Zirconium Oxide

Zirconium Hydroxide

Sodium Chloride

Sodium Fluoride

Rhodium oxide

Ruthenium Oxide

Palladium oxide

Sucrose

Sodium oxalate

Sodium Tetraborate Decahydrate

Boric Acid

Boric oxide

Sodium Monoxide
2.15

5.13

2.04

0.41

0.34

0.20

0.65

1.07

0.41

0.25

0.46

0.20

0.12

0.10

0.12

0.14

0.10

0.05

0.10

0.04

5.27

4.08

1.04

1.66

2.55

2.99

1.43

0.02

4.00

3.71

6.57

1.43

0.55

1.39

0.41

0.50

0.10

0.01

3.58

9.83

0.06

0.19

0.33

0.15

1.72

1.48

0.73

7.76

0.24

0.42

0.20

0.41

0.20

1.02

1. 32

0.06

0.06

0.06

0.06

0.06

4.12

9.69

8.39

5.44

3.06

2.77

$1 \mathrm{bs} / \mathrm{yr}$

Values given in limit/discharge per year column are maximum values permitted. Where no discharge limits are specified, actual 1997 discharge data has been provided. 
TABLE 3-3

WVDP ATMOS PHERIC REGUIATORY IIMITS (continued) *

Emission Pt./Description

14) (continued) CCF-Vessel ventilation system (CTS-03 - Cold Chem)

15) CCF-Dust Collection Hood (CTS-04 - Cold Chem)
Parameters

Sodium Nitrate

Sodium Nitrite

Zeolite

Total Solid Particulate

Nitric Acid

Acetic Acid

Formic Acid

Zirconyl Nitrate

Aluminum Hydroxide

Aluminum Nitrate

Aluminum oxide

Barium Hydroxide Octahydrate

Barium Nitrate

Barium oxide

Calcium Carbonate

Calcium Nitrate

Calcium Oxide

Cerium Hydroxide

Cerium Nitrate

Cerium oxide

Chromium oxide

Chromium oxide

Cesium Hydroxide Monohydrate

Cesium Nitrate

Cesium oxide

Copper Hydroxide

Copper Nitrate

Copper oxide

Iron oxide

Ferrous Nitrate

Potassium Hydroxide

Potassium Formate

Potassium Nitrate

Potassium oxide

Ianthanum oxide

Lithium Hydroxide Monohydrate

Iithium Formate

Iithium Nitrate

Iithium oxide

Magnesium Hydroxide

Magnesium Nitrate

Magnesium oxide

Manganese Oxide

Manganese Dioxide

Sodium Molybdate

Sodium Formate

Neodymium oxide

Nickel Hydroxide

Nickel Nitrate

Nickel oxide

Sodium Phosphate Monobasic

Sodium Sulfate

Silicon Oxide

strontium Hydroxide

Strontium Nitrate

strontium oxide

Titanium oxide

Zinc Oxide

Zirconium oxide

Zirconium Hydroxide

Sodium Chloride

Sodium Fluoride

Rhodium oxide

Ruthenium Oxide
Iimit/Discharge Per Yr.

$\begin{gathered}7.60 \\ 6.17 \\ 3.67 \\ 132.54 \\ 8.46 \\ 2.93 \mathrm{E}-1 \\ 6.70 \\ 2.21\end{gathered} \mid 1 \mathrm{bs} / \mathrm{yr}$

$\frac{1}{3} \cdot 34 \mathrm{E}-2$

$3 \cdot 28 \mathrm{E}-2$

$2.58 \mathrm{E}-3$

$2.14 \mathrm{E}-3$

$1.28 \mathrm{E}-3$

$4.06 \mathrm{E}-3$

$6.67 \mathrm{E}-3$

$2.55 \mathrm{E}-3$

$1.54 \mathrm{~F}-3$

2. $88 \mathrm{E}-3$

$1.28 \mathrm{E}-3$

$7.51 \mathrm{E}-4$

$6.38 \mathrm{E}-4$

$7.60 \mathrm{E}-4$

$8.82 \mathrm{E}-4$

6. $38 \mathrm{E}-4$

3. $13 \mathrm{E}-4$

$6.05 \mathrm{E}-4$

$2.55 \mathrm{E}-4$

$2.55 \mathrm{E}-2$

$6.52 \mathrm{E}-2$

1. $04 \mathrm{E}-2$

1. $60 \mathrm{E}-2$

$1.87 \mathrm{E}-2$

8.93E-3

1. $28 \mathrm{E}-4$

2. 5OE-2

2. 32E-2

$4.11 \mathrm{E}-2$

8. $93 \mathrm{E}-3$

3. $43 \mathrm{E}-3$

$8.71 \mathrm{E}-3$

$2.55 \mathrm{E}-3$

3. $13 \mathrm{E}-3$

6. $44 \mathrm{E}-4$

3. $65 \mathrm{E}-5$

$6.14 \mathrm{E}-2$

$3.83 \mathrm{E}-4$

$1.19 \mathrm{E}-3$

$2.08 \mathrm{E}-3$

$9.57 E-4$

1. $08 \mathrm{E}-2$

$4.53 \mathrm{E}-3$

$4.85 \mathrm{E}-2$

$1.50 \mathrm{E}-3$

$2.61 \mathrm{E}-3$

$1.28 \mathrm{E}-3$

$2.55 \mathrm{E}-3$

1. $28 \mathrm{E}-3$

$6.39 \mathrm{E}-3$

$8.25 \mathrm{E}-3$

$3.83 \mathrm{E}-4$

3. $83 \mathrm{E}-4$

$3.83 \mathrm{E}-4$

$3.83 \mathrm{E}-4$ 
WVDP-321

Rev. 0

Page 52 of 67

Palladium Oxide

$3.83 \mathrm{E}-4$

sucrose

$2.58 \mathrm{E}-2$

TABIE 3-3

WVDP ATMOSPHERIC REGUIATORY LIMITS (continued) *

Emission Pt./Description

15) (continued) CCF-Dust collection Hood

16) Source Capture Welding system (welding booth)

17) Tank 35157

18) Outdoor Vent Exhaust (permitted PVUs) No I.D. Numbers (mobile units not identified on map)

\section{Parameters}

Sodium Oxalate

Sodium Tetraborate Decahydrate Boric Oxide

Sodium Monoxide

Sodium Nitrate

Sodium Nitrite

Zeolite

Boric Acid

$\mathrm{NO}_{2}$

$\mathrm{CO}$

$\mathrm{CO}_{2}$

Ozone

Particulates

(Fe, Cr, Mn, Si, Ni,

Cu, Mo, P, S, C)

Exempt per 6NYCRR Part 2013.3 (33)

$$
\begin{aligned}
& \text { Alpha } \\
& \text { Beta } \\
& \text { Co-60 } \\
& \text { sr-90 } \\
& \text { Cs-134 } \\
& \text { Cs-137 } \\
& \text { Eu-154 } \\
& U-232 \\
& U-234 \\
& U-235 \\
& U-238 \\
& \text { Pu-238 } \\
& \text { Pu-239 } \\
& \text { Am-241 }
\end{aligned}
$$

Iimit/Discharge Per Yr.

$$
\begin{aligned}
& 6.05 \mathrm{E}-2 \\
& 5.24 \mathrm{E}-2
\end{aligned}
$$

1. $91 \mathrm{E}-2$

$1.73 \mathrm{E}-2$

4. $75 \mathrm{E}-2$

3. $86 \mathrm{E}-2$

2. $30 \mathrm{E}-2$

3.40

0.0868

1.70

119.00

$8.78 \mathrm{E}-3$

10.8

$1 \mathrm{bs} / \mathrm{yr}$

lbs/yr
2. $66 \mathrm{E}-10$
1. 20E-09
6. $27 \mathrm{E}-10$
3. $76 \mathrm{E}-10$
5. $16 \mathrm{E}-10$
4. $72 \mathrm{E}-10$
1. 38E-09
Ci/yr

9. $19 \mathrm{E}-10$

1. $09 \mathrm{E}-10$

3. 59E-11

1. $05 \mathrm{E}-10$

1. $73 \mathrm{E}-10$

6. $04 \mathrm{E}-11$

1. $09 \mathrm{E}-10$ 
TABLE 3-3

WVDP ATMOSPHERIC REGULATORY IIMITS (continued) *

Emission Pt. Description

\section{9) Solids Transfer} system (SVS01)
Parameters

Aluminum Hydroxide

Aluminum Nitrate

Aluminum oxide

Barium Hydroxide Octahydrate

Barium Nitrate

Barium oxide

Calcium Carbonate

Calcium Nitrate

Calcium oxide

Cerium Hydroxide

Cerium Nitrate

Cerium Oxide

Chromium oxide Hydrate

Chromium oxide

Cesium Hydroxide Monohydrate

Cesium Nitrate

Cesium oxide

Copper Hydroxide

Copper Nitrate

Copper Oxide

Iron Oxide

Ferrous Nitrate

Potassium Hydroxide

Potassium Formate

Potassium Nitrate

Potassium Oxide

Lanthanum oxide

Lithium Hydroxide Monohydrate

Lithium Formate

Lithium Nitrate

Lithium oxide

Magnesium Hydroxide

Magnesium Nitrate

Magnesium oxide

Manganese Dioxide

Manganese Oxide

Sodium Molybdate

Sodium Formate

Neodymium oxide

Nickel Hydroxide

Nickel Nitrate

Nickel Oxide

Sodium Phosphate Monobasic

Sodium sulfate

Silicon oxide

strontium Hydroxide

strontium Nitrate

strontium oxide

Titantium oxide

zinc oxide

Zirconium oxide

Zirconium Hydroxide

Sodium Chloride

Sodium Fluoride

Rhodium oxide

Ruthenium Oxide

Palladium Oxide

Sucrose

Sodium oxalate

Sodium Tetraborate Decahydrate
Iimit/Discharge Per Yr.

$1.92 \mathrm{E}-3$

$4.58 \mathrm{E}-3$

1. $82 \mathrm{E}-3$

$3.68 \mathrm{E}-4$

3. $04 \mathrm{E}-4$

1. $82 \mathrm{E}-4$

$5.79 \mathrm{E}-4$

9.52E-4

3. $65 \mathrm{E}-4$

2. 21E-4

4. $12 E-4$

1. $82 \mathrm{E}-4$

$1.08 \mathrm{E}-4$

9. $12 E-5$

1. $10 \mathrm{E}-4$

$1.26 \mathrm{E}-4$

$9.12 \mathrm{E}-5$

$4.56 \mathrm{E}-5$

8. $54 \mathrm{E}-5$

3. $65 \mathrm{E}-5$

3. $65 \mathrm{E}-3$

$9.34 \mathrm{E}-3$

$1.48 \mathrm{E}-3$

$2.28 \mathrm{E}-3$

$2.67 \mathrm{E}-3$

1. $28 \mathrm{E}-3$

$1.82 \mathrm{E}-5$

$3.57 \mathrm{E}-3$

3. $32 \mathrm{E}-3$

$5.85 \mathrm{E}-3$

$1.28 \mathrm{E}-3$

4. $90 \mathrm{E}-4$

1. $24 \mathrm{E}-3$

3. $65 \mathrm{E}-4$

$4.47 \mathrm{E}-4$

3. $65 \mathrm{E}-4$

$5.50 \mathrm{E}-6$

$8.77 \mathrm{E}-3$

$5.47 \mathrm{E}-5$

1.70E-4

3. $04 \mathrm{E}-4$

1. $37 \mathrm{E}-4$

1. $54 \mathrm{E}-3$

$6.48 \mathrm{E}-4$

$6.94 E-4$

2. $13 E-4$

3. $72 \mathrm{E}-4$

1. $82 \mathrm{E}-4$

$3.65 \mathrm{E}-4$

1. $82 E-4$

9. $12 E-4$

1. $18 \mathrm{E}-3$

$5.47 E-5$

$5.47 \mathrm{E}-5$

$5.47 E-5$

$5.47 \mathrm{E}-5$

$5.47 \mathrm{E}-5$

3. $68 \mathrm{E}-3$

8. $66 \mathrm{E}-3$

$7.51 \mathrm{E}-3$ 
TABLE 3-3

WVDP ATMOSPHERIC REGUIATORY IIMITS (continued)*

Emissien Pt. Description

19 (continued) Solids

Transfer system (SVS01)

20) Vessel Vent off-Gas system (svs02)
Parameters

Boric Acid

Boric oxide

Sodium Monoxide

Sodium Nitrate

Sodium Nitrite

Zeolite (IE-96/IE-95)

Total Solid Particulates

Aluminum Hydroxide

Aluminum Nitrate

Aluminum oxide

Barium Hydroxide octahydrate

Barium Nitrate

Barium oxide (Nitrate)

Calcium Carbonate

Calcium Nitrate

Calcium oxide

Cerium Hydroxide

Cerium Nitrate

Cerium oxide (Nitrate)

Chromium oxide Hydrate

Chromium oxide

Cesium Hydroxide Monohydrate

Cesium Nitrate

Cesium Oxide

Copper Hydroxide

Copper Nitrate

Copper oxide

Iron oxide

Ferrous Nitrate

Potassium Hydroxide

Potassium Formate

Potassium Nitrate

Potassium Oxide

Lanthanum oxide

Lithium Hydroxide Monohydrate

Iithium Formate

Iithium Nitrate

Iithium oxide

Magnesium Hydroxide

Magnesium Nitrate

Magnesium oxide

Manganese Dioxide

Manganese oxide

Sodium Molybdate

Sodium Formate

Neodymium oxide

Nickel Hydroxide

Nickel Nitrate

Nickel oxide

Sodium Phosphate Monobasic

Sodium sulfate

Silicon Oxide

Strontium Hydroxide

Strontium Nitrate

strontium oxide

Titantium oxide

zinc oxide
Limit/Discharge Per Yr.

$4.86 \mathrm{E}-3$

$2.73 \mathrm{E}-3$

$2.48 E-3$

$6.76 \mathrm{E}-3$

$5.51 E-3$

$3.28 \mathrm{E}-3$

592

los/yr

6. $42 \mathrm{E}-1$

1.52

6. 08E-1

1. $23 E-1$

$1.01 \mathrm{E}-1$

6. $1 \mathrm{E}-2$

1. $94 \mathrm{E}-1$

3. $17 \mathrm{E}-1$

1. $22 \mathrm{E}-1$

7. $3 \mathrm{E}-2$

1. $38 \mathrm{E}-1$

6. $1 E-2$

3. $6 \mathrm{E}-2$

3. $O E-2$

3. $6 \mathrm{E}-2$

4. $2 E-2$

3. $O E-2$

1. 5E-2

2. $9 \mathrm{E}-2$

1. $2 \mathrm{E}-2$

1. 21

3.10

4. $94 \mathrm{E}-1$

7. $62 \mathrm{E}-1$

8. $89 \mathrm{E}-1$

4. $25 E-1$

6. $O E-3$

1.19

1.10

1.95

4. $25 E-1$

1. $63 \mathrm{E}-1$

4. 15E-1

1. $22 \mathrm{E}-1$

1. $22 \mathrm{E}-1$

1. $49 \mathrm{E}-1$

2. OE-3

2.93

1. $8 \mathrm{E}-2$

5. $7 E-2$

1. $01 \mathrm{E}-1$

4. $6 \mathrm{E}-2$

5. $14 \mathrm{E}-1$

2. 16E-1

2. 31

7. $1 E-2$

1. $24 \mathrm{E}-1$

6. $1 E-2$

1. $22 \mathrm{E}-1$

6. $1 E-2$ 
WVDP-321

Rev. 0

Page 55 of 67

\section{WVDP ATMOSPHERIC REGUIATORY LIMITS (concluded) *}

Emission Pt. Description

20 (continued) Vessel Vent off-Gas system (svs02)

21) Mini Melter off-Gas vent system (SVS04)

\section{Parameters}

Zirconium oxide

Zirconium Hydroxide

sodium Chloride

Sodium Fluoride

Rhodium oxide

Ruthenium oxide

Palladium oxide

Sucrose

Sodium Oxalate

Sodium Tetraborate Decahydrate

Boric Acid

Boric oxide

Sodium Monoxide

Sodium Nitrate

sodium Nitrite

Zeolite (IE-96/IE-95)

Total solid Particulate

Nitric Acid

Phosphoric Acid

Ferric Hydroxide

Formic Acid

Sodium Hydroxide

Zirconyl Nitrate

Particulates

Nitrogen oxides

sulfur oxides

Ammonia (anhydrous)

Carbon oxides

Fluorides

Chlorides

\section{Limit/Discharge Per Yr.}

22) Vitrification

Off-Gas System (Main Melter)

$\mathrm{NO}_{\mathrm{x}}$

$\frac{1}{\star} \star_{\star}^{\star} 31$

3. $04 E-1$
$3 \cdot 93 E-1$
$1.8 E-2$

1. $8 \mathrm{E}-2$

$1.8 \mathrm{E}-2$

$1.8 E-2$

1. $8 \mathrm{E}-2$

1.22

2.88

2.50

1.61

$9.12 \mathrm{E}-1$

$8.26 \mathrm{E}-1$

2.26

1.83

38.66

$1 \cdot 18 \mathrm{E}-3$

8.78

3. $18 \mathrm{E}-1$

$3.5 \mathrm{E}-2$

2.12E-1

$1.33 \mathrm{E}-1$

412
$\star \star$
$\star \star$

1.24

$3 \cdot 31$

$6 \cdot 6$

23) Vitrification

Facility HVAC system

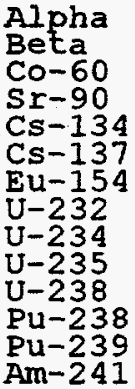

Chromium

Nickel
2. $66 \mathrm{E}-10$

1. $20 \mathrm{E}-09$

$3.76 \mathrm{E}-10$

$5 \cdot 16 \mathrm{E}-10$

4. $72 \mathrm{E}-10$

1. 38E-09

$9.19 \mathrm{E}-10$

1. $09 \mathrm{E}-10$

3. $59 \mathrm{E}-11$

$1.05 \mathrm{E}-10$

$1.73 \mathrm{E}-10$

6.04E-11

1.09E-10

$2.36 \mathrm{E}-7$
$1.41 \mathrm{E}-7$

Exempt per 6 NYCRR Part 2013.2 (40)

Exempt per 6 NYCRR Part 2013.3 (33)

Exempt per 6 NYCRR Part 2013.3 (33)
26) svsos Emergency Vent

27,28 ) Boilers
$\mathrm{NO}_{\mathrm{S}}$
Ibs/yr

$1 \mathrm{bs} / \mathrm{yr}$
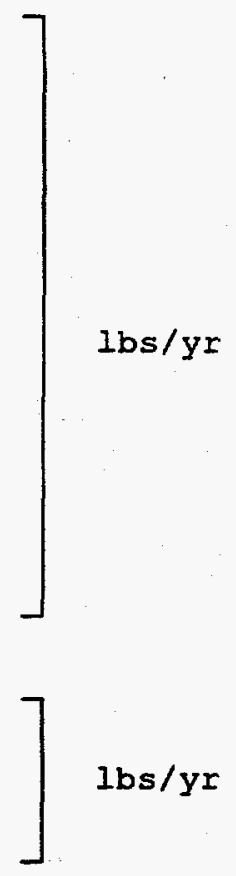

$\int$ tons/yr

Ci/yr

lbs/yr
24) Environmental Lab Fume Hoods

25) Svs03 Emergency Vent

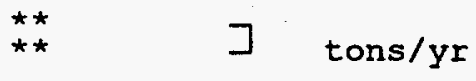

- Values given in limit/discharge per year column are maximum values permitted. Where no discharge limits are specified, actual 1997 discharge data has been provided.

* WVDP is subject to a 100 ton/year cap for both $\mathrm{NO}_{\mathrm{x}}$ and $\mathrm{SO}_{2}$ emissions. Therefore, hourly and annual limits for individual sources are not used. Totals for all stacks are compiled and submitted to NYSDEC annually. 
WVDP-321

Rev. 0

Page 56 of 67

THIS PAGE INTENTIONALLY LEFT BLANK 
Table 3-4

West Valley Demonstration Project Nonradiological fiquid Regulatory Limits

\begin{tabular}{|c|c|c|c|}
\hline outfall & Parameter & Daily Maximum Limit (1) & Sample Erequency \\
\hline $\begin{array}{l}001 \text { (Process and } \\
\text { storm Waste water) }\end{array}$ & 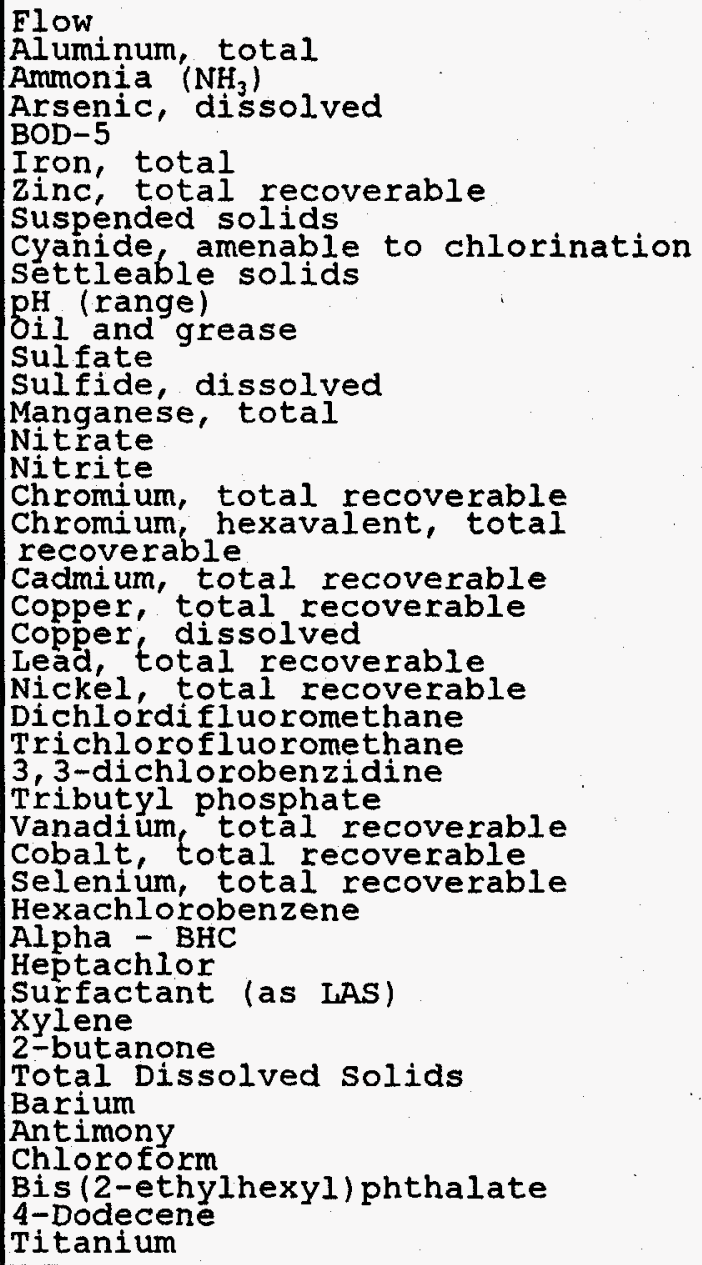 & 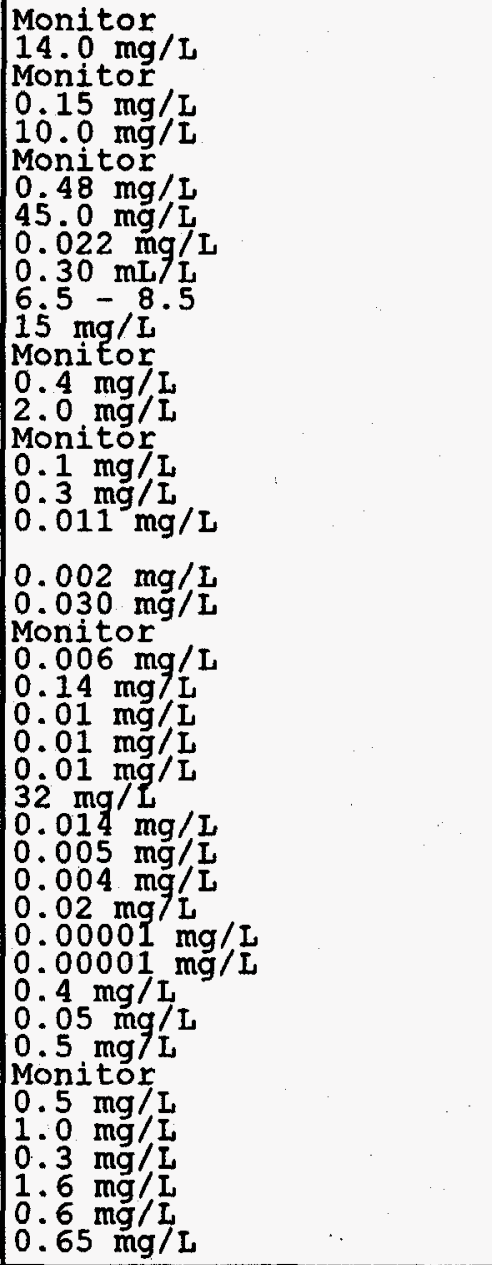 & 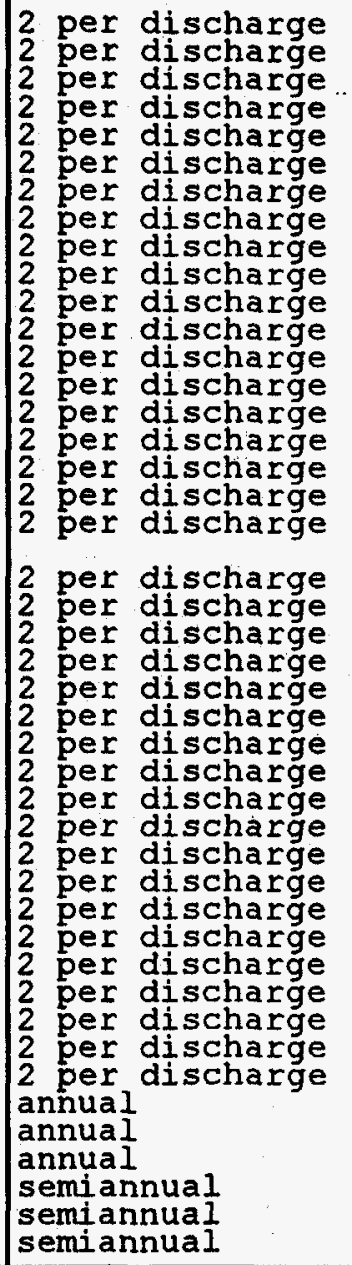 \\
\hline
\end{tabular}

(1) Daily average limitations are also identified in the permit but require monitoring only for every parameter except aluminum, total (daily average limit - $7.0 \mathrm{mg} / \mathrm{L}$ ); solids, suspended (daily average limit - $30.0 \mathrm{mg} / L$ ); BOD-5 for the sum of outfalls 001,007 , and 008 (daily average limit - $5.0 \mathrm{mg} / \mathrm{L}$ ); and ammonia for the sum of outfalls 001 and 007 (daily average limit - $1.49 \mathrm{mg} / \mathrm{L}$ ). 
WVDP-321

Rev. 0

Page 58 of 67

Table 3-4 (concluded)

West Valley Demonstration Project Nonradiological Liquid Regulatory Imits

\begin{tabular}{|c|c|c|c|}
\hline outfall & Parameter & Daily Maximum Limit (1) & Sample Frequency \\
\hline $\begin{array}{l}007 \text { (Sanitary and } \\
\text { utility Wastewater) }\end{array}$ & $\begin{array}{l}\text { Flow } \\
\text { Ammonia (as } \mathrm{NH}_{3} \text { ) } \\
\text { BOD-5 } \\
\text { Iron, total } \\
\text { Solids, suspended } \\
\text { Solids, settleable } \\
\text { pH (range) } \\
\text { Nitrite (as } \mathrm{N} \text { ) } \\
\text { Oil and grease } \\
\text { Chlorine, total residual } \\
\text { Chloroform }\end{array}$ & $\begin{array}{l}\text { Monitor } \\
\text { Monitor } \\
10.0 \mathrm{mg} / \mathrm{L} \\
\text { Monitor } \\
45.0 \mathrm{mg} / \mathrm{L} \\
0.30 \mathrm{~mL} / \mathrm{L} \\
6.5-8.5 \\
0.1 \mathrm{mg} / \mathrm{I} \\
15 \mathrm{mg} / \mathrm{L} \\
0.1 \mathrm{mg} / \mathrm{L} \\
0.20 \mathrm{mg} / \mathrm{L}\end{array}$ & $\begin{array}{l}3 \text { per month } \\
3 \text { per month } \\
3 \text { per month } \\
3 \text { per month } \\
3 \text { per month } \\
\text { weekly } \\
\text { weekly } \\
3 \text { per month } \\
3 \text { per month } \\
\text { weekly } \\
\text { annual }\end{array}$ \\
\hline $\begin{array}{l}008 \text { (Erench Drain } \\
\text { Wastewater) }\end{array}$ & $\begin{array}{l}\text { Flow } \\
\text { BOD-5 } \\
\text { Iron, total } \\
\text { pH (range) } \\
\text { Cadmium, total recoverable } \\
\text { Lead, total recoverable } \\
\text { Silver, total } \\
\text { 2inc, total } \\
\text { Arsenic } \\
\text { Chromium }\end{array}$ & $\begin{array}{l}\text { Monitor } \\
5.0 \mathrm{mg} / \mathrm{I} \\
\text { Monitor } \\
6.5-8.5 \\
0.002 \mathrm{mg} / \mathrm{L} \\
0.006 \mathrm{mg} / \mathrm{L} \\
0.008 \mathrm{mg} / \mathrm{L} \\
0.100 \mathrm{mg} / \mathrm{I} \\
0.17 \mathrm{mg} / \mathrm{L} \\
0.13 \mathrm{mg} / \mathrm{L}\end{array}$ & $\begin{array}{l}3 \text { per month } \\
3 \text { per month } \\
3 \text { per month } \\
3 \text { per month } \\
3 \text { per month } \\
3 \text { per month } \\
\text { annual } \\
\text { annual } \\
\text { annual } \\
\text { annual }\end{array}$ \\
\hline $\begin{array}{l}\text { Sum of Outfalls 001, } \\
007, \text { and } 008\end{array}$ & $\begin{array}{l}\text { Iron, total } \\
\text { BOD-5 }\end{array}$ & $\begin{array}{l}0.30 \mathrm{mg} / \mathrm{L} \\
\text { Monitor }\end{array}$ & $\begin{array}{l}3 \text { per month } \\
3 \text { per month }\end{array}$ \\
\hline $\begin{array}{l}\text { Sum of Outfalls } 001 \\
\text { and } 007\end{array}$ & Ammonia $\left(\mathrm{NH}_{3}\right)$ & $2.1 \mathrm{mg} / \mathrm{L}$ & 3 per month \\
\hline $\begin{array}{l}\text { Pseudo monitoring } \\
\text { point } 116 \quad \text { (2) }\end{array}$ & Solids, total dissolved & $500 \mathrm{mg} / \mathrm{L}$ & 2 per discharge \\
\hline
\end{tabular}

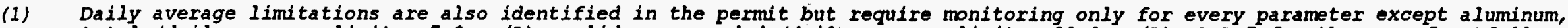
total (daily average limit - $7.0 \mathrm{mg} / \mathrm{L}$ ); solids, suspended (daily average 1 imit - $30.0 \mathrm{mg} / \mathrm{L}$ ); BOD-5 for the sum of outfalls 001 , 007, and 008 (daily average limit - $5.0 \mathrm{mg} / \mathrm{L}$ ); and ammonia for the sum of outfalls 001 and 007 (daily average limit $1.49 \mathrm{mg} / \mathrm{L}$ ).

(2) Oufall 116 is a point where compliance with the SPDEs permit limit for Total Dissolved solids is maintained through calculation using monitoring data from upstream sources representing flows from Frank's Creek and Erdman Brook. 
WVDP-321

Rev. 0

Page 59 of 67

TABLE 3-5

COMPARISON OF ORIGINAL AND MODIFIED WVDP OCCUPATIONAL DOSE DUE TO ROUTINE ORERATIONS (PERSON-REM)

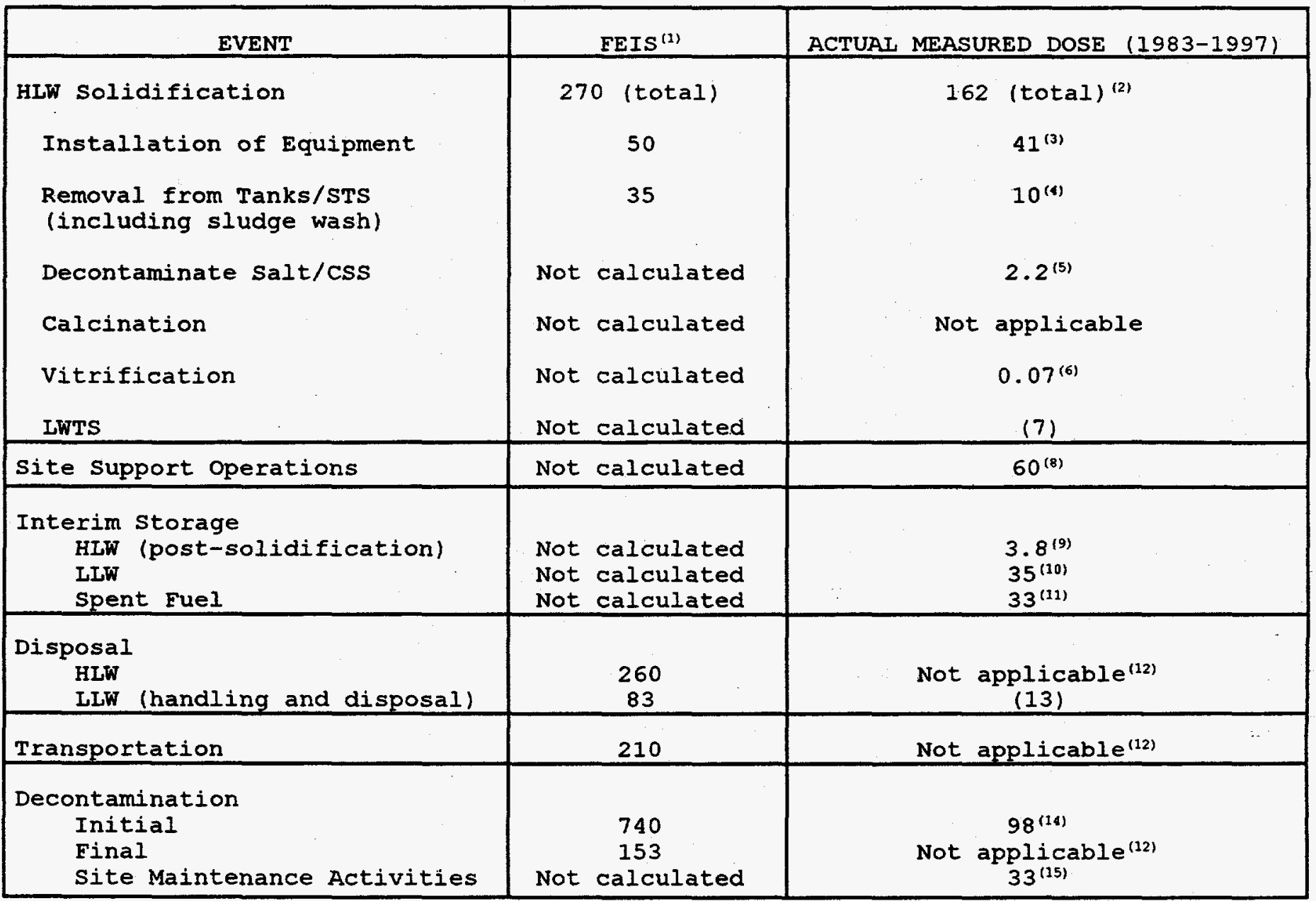

(1) U.S. Department of Energy. 1982, DOE/EIS-0081. Table 4.11

(2) Inciudes all data for How solidification activities as a whole, including all events listed below under HLW solidification; also includes 1983 - 1997 ALARA Exposure Group data for groups unique to this category such as chemistry, rad control, rad projects, radiochemistry, IRTs processing, analyt/enviro chem, and vit design/eng (3) 1983 - 1995 ALARA Exposure Group data for groups that include ali construction and instrumentation

(4) 1987 - 1992 AIARA Exposure Group data for groups that include sTs ops and

(5) 1991 - 1996 AfARA Exposure Group data for groups that include LWTS/CSS ops

(6) 1996 - 1997 AIARA Exposure Group data for groups that include vit ops/readiness/process and melting ops

(7) Dose included with Decontaminate salt/css

(8) 1983 - 1997 AIARA Exposure Group data for all reported site groups not addressed in the remainder of table, including proj control, plant security, plant ops, environ affairs, saf \& env assess, eng design etc.

(9) 1996 - 1997 AIARA Exposure Group data for groups that include waste handling and waste management ops

(10) 1987 - 1995 ALARA Exposure Group data for groups that include site/waste maint, low level ops, waste handing ops, waste eng, and low level eng/staff

(11) 1983 - 1997 AIARA Exposure Group data fór groups that include fuel/site projects and fuel programs

(12) To be adaressed in EIS for Completion of WVDP and Closure or Long-term Management of WNYNSC (DOE/EIS-0226-D)

(13) Dose included with Interim storage - LLW

(14) 1983 - 1989 ALARA Exposure Group data for groups that include $D \& D$ engr, $D \& D$ ops, and

(15) 1983 - 1997 AIARA Exposure Group data for groups that include Elec/I\&C maint, maint, and maint sub.

Note: AIARA Exposure Group data taken from annual ALARA Performance summary reports 
WVDP-321

Rev. 0

Page 60 of 67

THIS PAGE INTENTIONALLY LEFT BLANK

WVDP: 0006405.01 
WVDP-321

Rev. 0

Page 61 of 67

TABLE 3-6

COMPARISON OF ORIGINAI AND MODIFIED WVDP SHORT-TERM RADIOLOGICAL DOSES DUE TO ROUTINE OPERATION

OFF-SITE MAXIMUM INDIVIDUAL DOSE (REM)

\begin{tabular}{|c|c|c|c|}
\hline EVENT & FEIS & SAR & $\begin{array}{c}\text { WVDP SER Estimated } \\
\text { Maximum Off-site } \\
\text { Dose }\end{array}$ \\
\hline $\begin{array}{l}\text { HLW Solidification } \\
\text { Removal from Tanks } \\
\text { STS } \\
\text { Decontaminate salt/ } \\
\text { CSSCalcination } \\
\text { Vitrification } \\
\text { LwTS }\end{array}$ & $2 \begin{array}{c}3 \times 10^{-5} \\
2 \times 10^{-4}(\text { total })\end{array}$ & $\begin{array}{l}2.3 \times 10^{-4} \text { (2) } \\
3 \times 10^{-7}(3) \\
5.8 \times 10^{-4} \text { (4) (liq.) } \\
\text { Not applicable } \\
1.2 \times 10^{-5}(5) \\
4.3 \times 10^{-4}(6)\end{array}$ & ${ }^{1.6} \times{ }_{(\operatorname{total})^{10}}^{10^{-3}}$ \\
\hline $\begin{array}{l}\text { Interim storage } \\
\text { HLW (post- } \\
\text { solidification) } \\
\text { LLW } \\
\text { spent Fuel }\end{array}$ & $\begin{array}{l}\text { Negligible } \\
\text { Negligible } \\
\text { Not calculated }\end{array}$ & $\begin{array}{c}\text { Not calculated } \\
\text { Not calculated } \\
2.8 \times 10^{-8}\left(\text { gas) } \text { (Annual) }_{(\text {Annual) }}^{(8)}\right.\end{array}$ & $\begin{array}{l}\text { Not calculated } \\
\text { Not calculated } \\
\text { Not calculated }\end{array}$ \\
\hline Disposal & Negligible & (7) & $(7)$ \\
\hline Transportation & $2 \times 10^{-3}$ & Not calculated & Not calculated \\
\hline $\begin{array}{c}\text { Decontamination } \\
\text { Initial } \\
\text { Final }\end{array}$ & $\begin{array}{l}5 \times 10^{-4} \\
1 \times 10^{-2}\end{array}$ & $\begin{array}{c}\text { Not calculated } \\
\text { (7) }\end{array}$ & $\begin{array}{c}\text { Not calculated } \\
\text { (7) }\end{array}$ \\
\hline
\end{tabular}

(1) U.S. Department of Energy. 1982. DOE/EIS-0081. Table 4-6

(2) Orig. SAR-004, Rev. 7, Supernatant Treatment system (STS) SAR, Table D.8.6-1

(3) Orig. SAR-008, Rev. 1, Cement Solidification System (CSS) SAR, Table G.8.6-2

(4) Orig. SAR-008, Rev. 1, Cement Solidification system (CSS) SAR, Table G.8.6-3

(5) Orig. SAR-003, Rev. 1, Vitrification system PSAR, Table C.8.6-1

(6) Orig. SAR-005, Rev. 3, Liquid Waste Treatment system (LWTS) SAR. Table H.8.6-2

(7) To be addressed in the WVDP Site Closure EIS (DOE/EIS-0226-D)

(8) Addendum 1 to orig. SAR for Existing Plant and operations, Volume II, Part B, FRS Facilities

(9) Total Estimated Dose to Maximum Exposed off-site Individual from 1983 - 1997 Site Environmental Reports; includes airborne releases from 1983 - 1984 and both airborne and waterborne releases from 1985 - 1997; data from 1993 - 1997 include North Plateau Drainage. 
WVDP-321

Rev. 0

Page 62 of 67

THIS PAGE INTENTIONALLY LEFT BLANK 
WVDP-321

Rev. 0

Page 63 of 67

TABLE 3-7 COMPARISON OF EIS INCREMENTAI COLLECTIVE POPULATION DOSE ${ }^{1}$ PREDICTIONS WITH
DOSES REPORTED IN THE ANNUAI SITE ENVIRONMENTAL REPORTS (1982-1997)

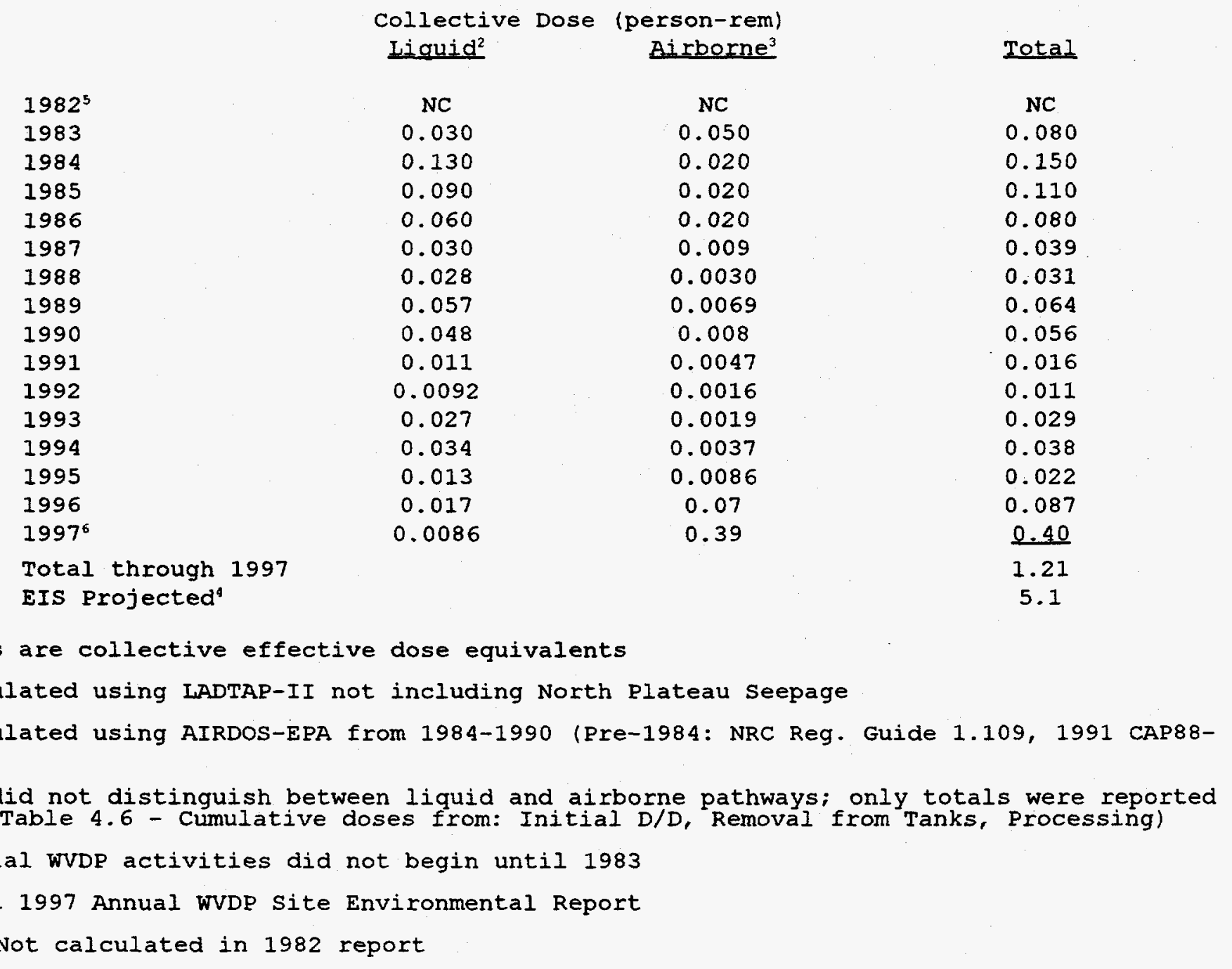

WVDP:0006405.01 


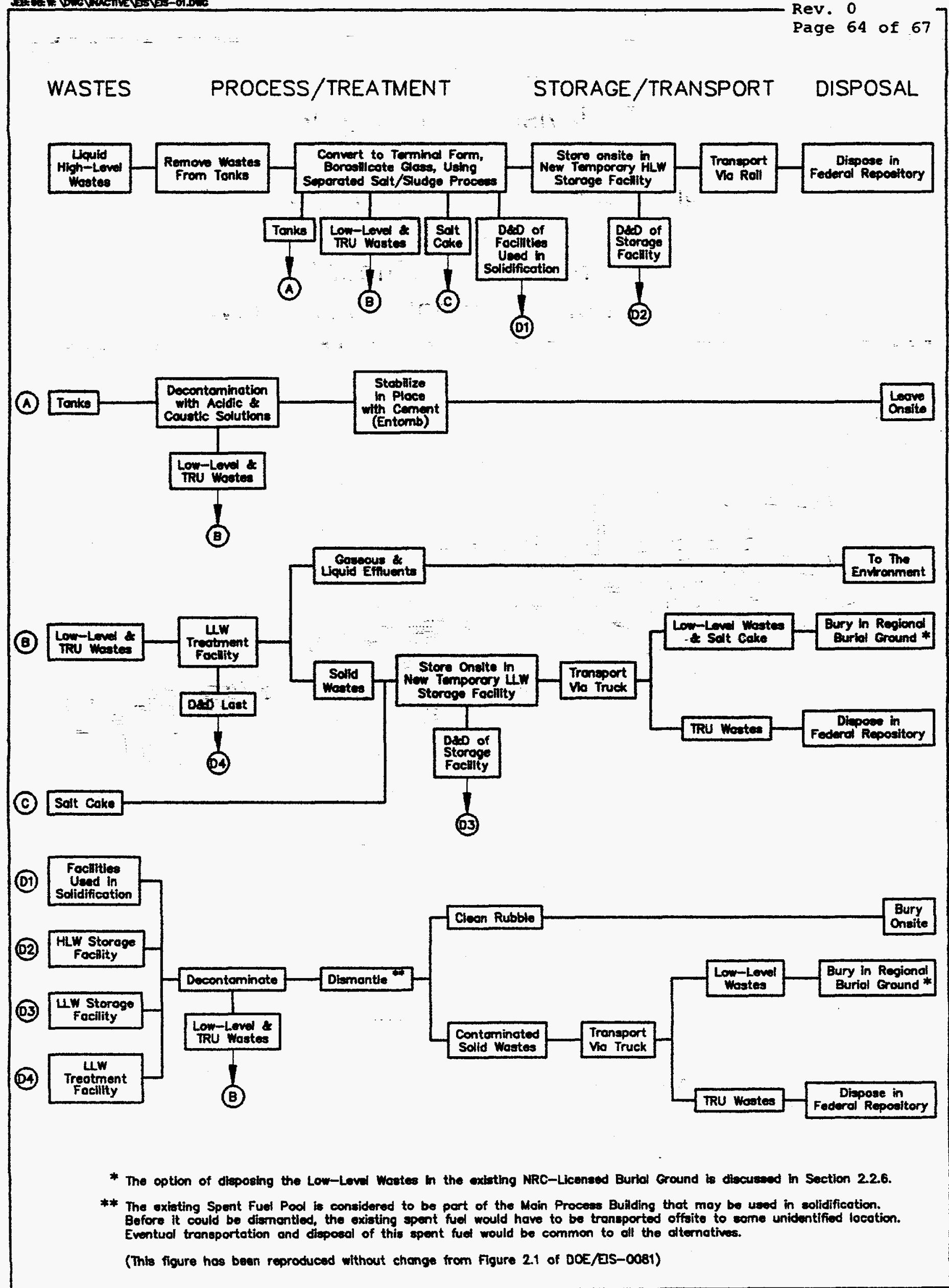

Figure 2-1. Original WVDP Process Per FEIS (DOE/EIS-0081) 


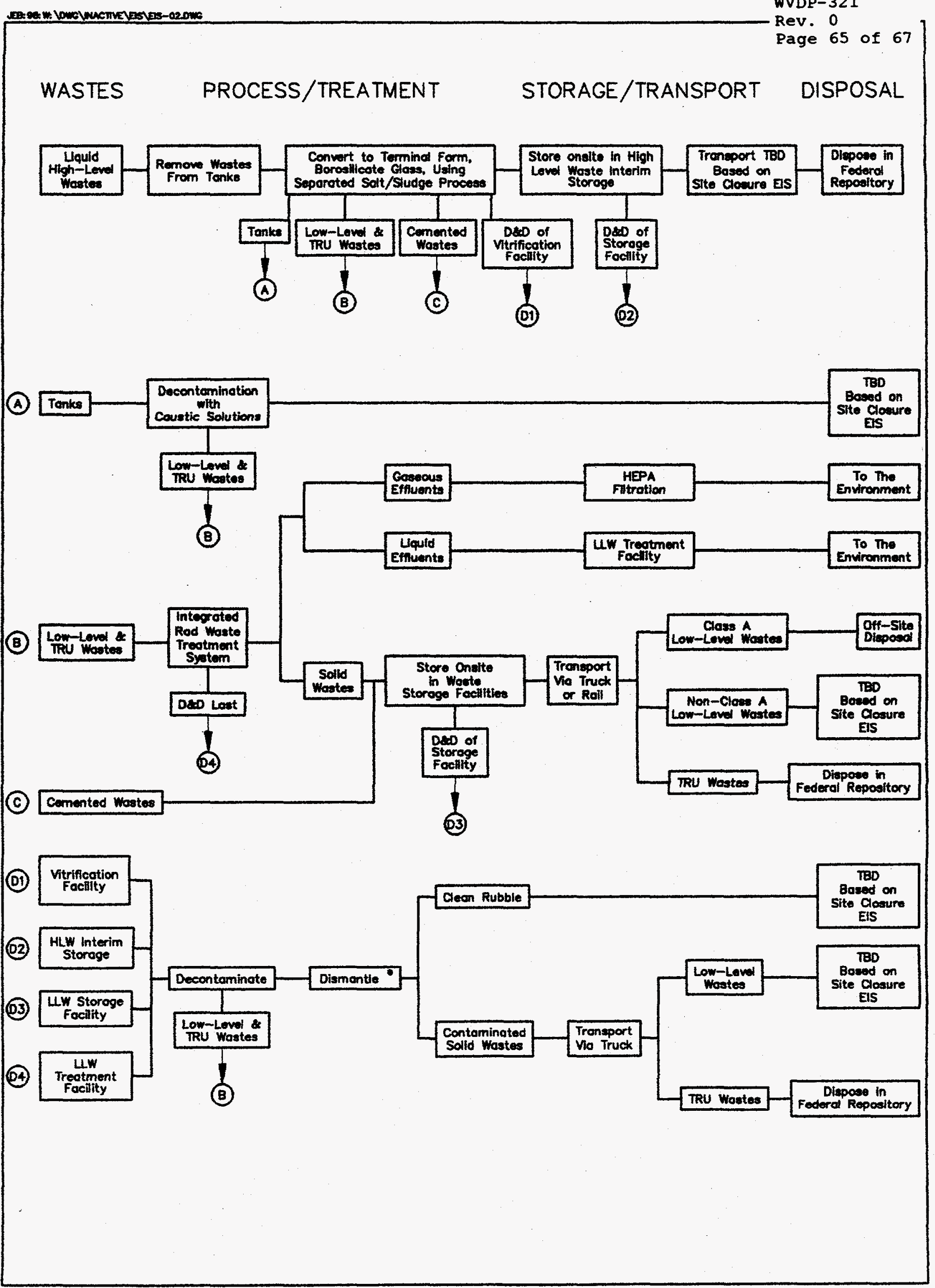


WVDP-321

Rev. 0

Page 66 of 67

ABB: 98: W: \OWG YNACNVE\EIS \EIS-03.DWG

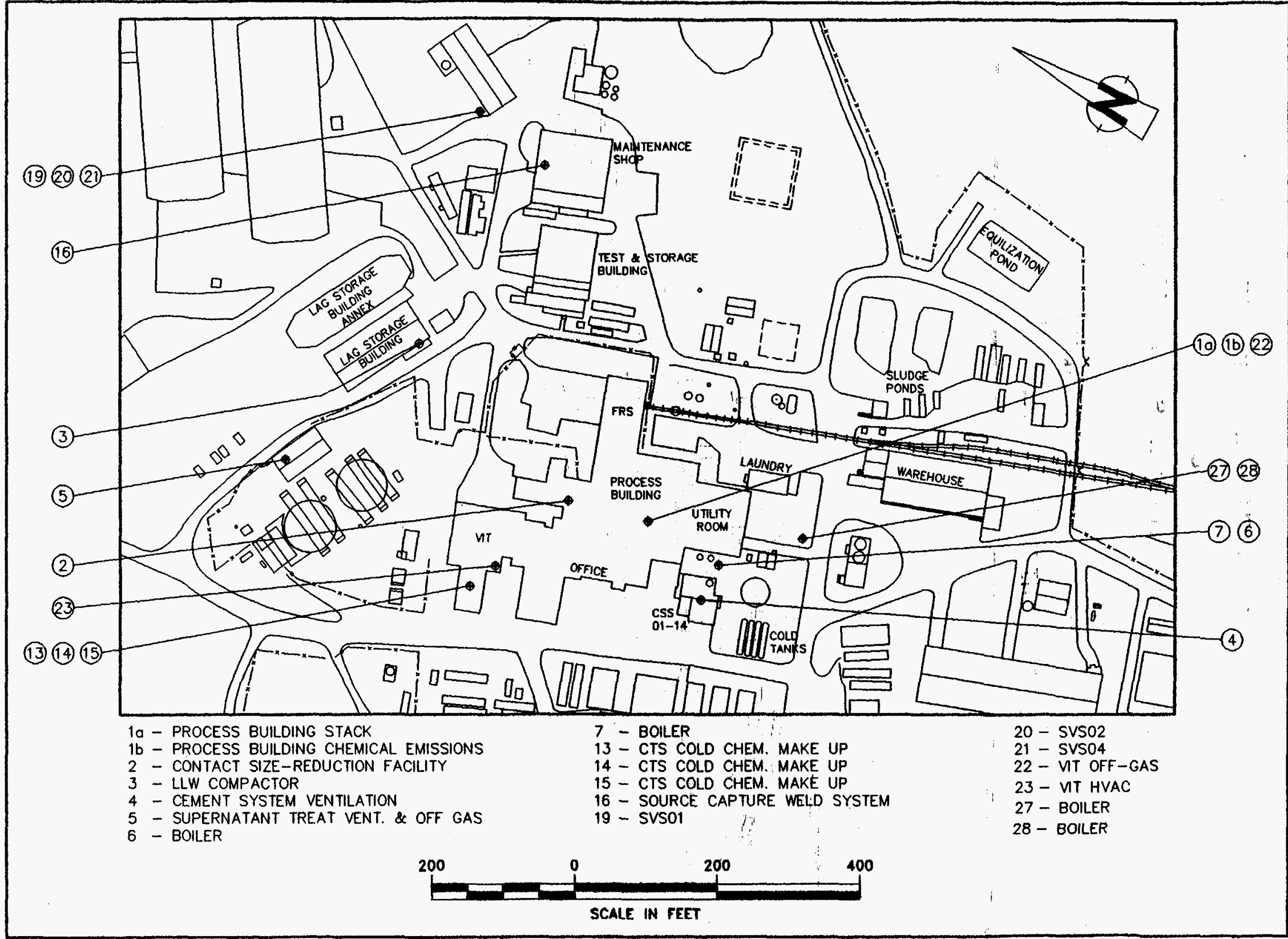

Figure 3-1

PERMITTED AIR DISCHARGE POINTS 


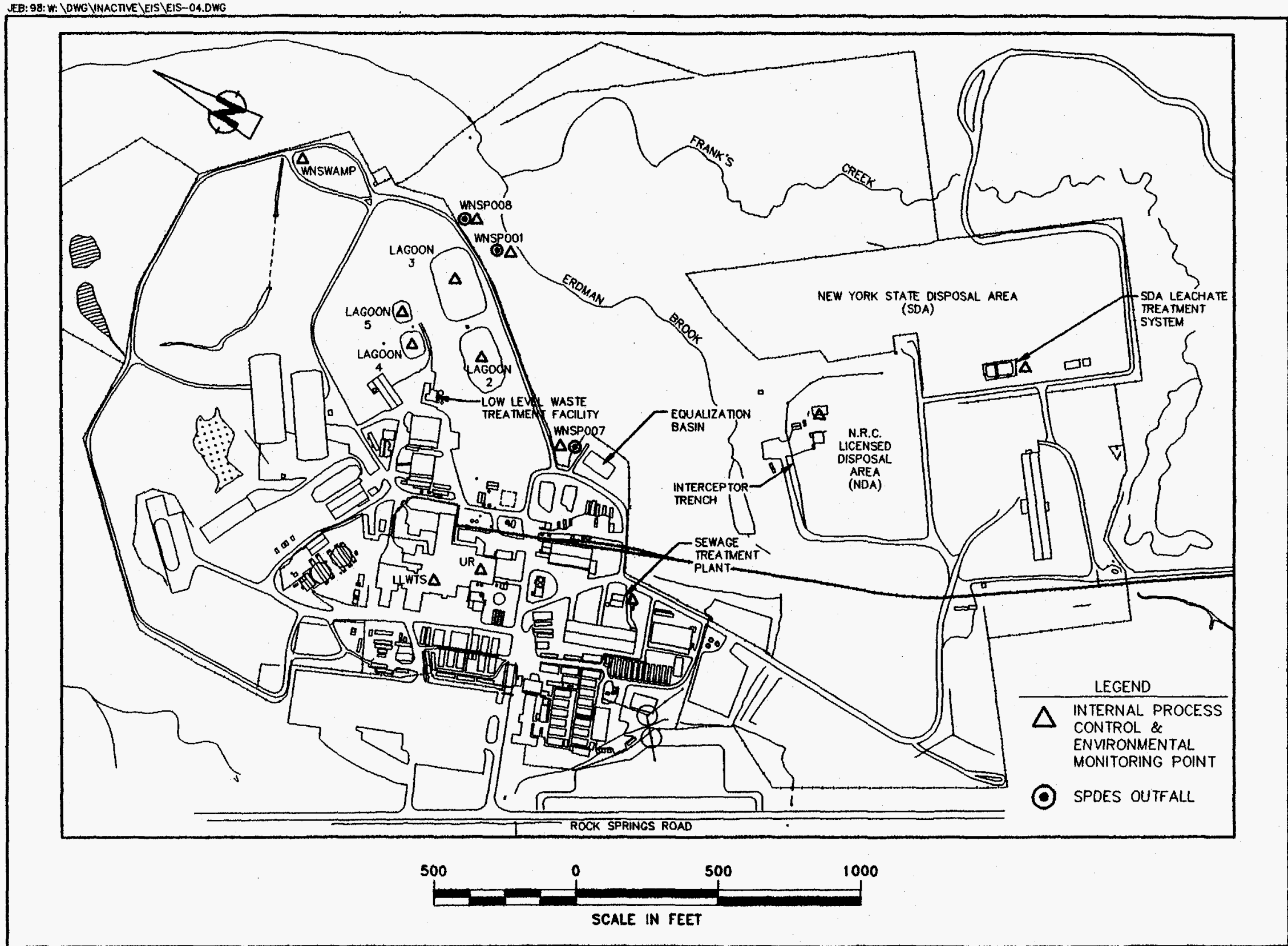

Figure 3-2 